This item was submitted to Loughborough's Research Repository by the author.

Items in Figshare are protected by copyright, with all rights reserved, unless otherwise indicated.

\title{
Invasive species influence macroinvertebrate biomonitoring tools and functional diversity in British rivers
}

PLEASE CITE THE PUBLISHED VERSION

https://doi.org/10.1111/1365-2664.13795

\section{PUBLISHER}

Wiley

VERSION

AM (Accepted Manuscript)

\section{PUBLISHER STATEMENT}

This is the peer reviewed version of the following article: GUARESCHI, S. ... et al, 2021. Invasive species influence macroinvertebrate biomonitoring tools and functional diversity in British rivers. Journal of Applied Ecology, 58 (1), pp.135-147, which has been published in final form at https://doi.org/10.1111/13652664.13795. This article may be used for non-commercial purposes in accordance with Wiley Terms and Conditions for Use of Self-Archived Versions.

\section{LICENCE}

CC BY-NC-ND 4.0

\section{REPOSITORY RECORD}

Guareschi, Simone, Alex Laini, Judy England, Tim Johns, Martin Winter, and Paul Wood. 2021. "Invasive Species Influence Macroinvertebrate Biomonitoring Tools and Functional Diversity in British Rivers". Loughborough University. https://hdl.handle.net/2134/13567499.v1. 


\section{Invasive species influence macroinvertebrate biomonitoring tools and functional diversity in} British rivers

3

Simone Guareschi ${ }^{1}$, Alex Laini ${ }^{2}$, Judy England ${ }^{3}$, Tim Johns ${ }^{3}$, Martin Winter ${ }^{3}$, Paul J Wood ${ }^{1}$

1 Geography and Environment, Loughborough University, Loughborough, Leicestershire, LE11 3TU, England, UK 2 Department of Chemistry, Life Sciences and Environmental Sustainability, University of Parma, Parco Area delle Scienze 11/A, 43124 Parma, Italy

3 Environment Agency, Horizon House, Deanery Rd, Bristol BS1 5AH, United Kingdom

Corresponding author: Simone Guareschi, email: S.Guareschi@lboro.ac.uk

SG ORCID: 0000-0003-2962-0863

Keywords: biological invasions, bioassessment, demon shrimp, fluvial systems, functional indices, waterbody assessment, freshwater, Dikerogammarus
This article has been accepted for publication and undergone full peer review but has not been through the copyediting, typesetting, pagination and proofreading process, which may lead to differences between this version and the Version of Record. Please cite this article as doi: 


\section{Abstract}

1. Biological invasions could have major implications for the management and conservation of freshwater systems if they lead to a misclassification of waterbodies. However, there is limited understanding of the sensitivity of existing biomonitoring tools to invasive species in rivers; and even less known regarding how they influence community taxonomic and functional measures.

2. This research explores the response of freshwater macroinvertebrate communities to biological invasion using taxonomic and functional indices. Utilising a long-term dataset (spanning 2000-2019, 5,988 samples) from rivers in England, the performance of four biomonitoring tools (WHPT, WHPTASPT, LIFE, PSI) and two community functional indices (functional richness and redundancy) were examined before and after the colonisation of the invasive species, Dikerogammarus haemobaphes (Eichwald, 1841) (Crustacea: Gammaridae). This species represents a recent (first record 2012) and highly successful invader, allowing its range expansion within waterbodies to be examined in detail. Spatial (national and basin level) and seasonal (spring and autumn) effects were investigated using a Before-After Control-Impact (BACI) experimental framework and linear mixed effects models.

3. Results indicated that invasion by D. haemobaphes resulted in significant reductions to the WHPT index and functional diversity metrics (richness and redundancy) while more subtle patterns were observed for other metrics. Analysis of seasonal and individual river basins (River Trent and R. Thames) identified largely consistent responses. The establishment of $D$. haemobaphes also resulted in some modifications to the functional composition of aquatic communities primarily associated with voltinism and resistance form features.

4. Synthesis and applications. Our findings indicate that D. haemobaphes should be considered a significant pressure to riverine communities. These results have implications for biomonitoring which informs managerial actions as effects may not be detected using a single taxonomic index. Community functional measures are useful in characterising the effects of invasive species and may form a valuable part of the "toolbox" used for studying biological invasions in rivers. The research illustrates the need to consider the wider threats posed by invasive species on the long-term integrity of freshwaters and the efficacy of freshwater biomonitoring tools. 
Abstract in Spanish: Las especies invasoras influyen en las herramientas de biomonitoreo de macroinvertebrados y en la diversidad funcional de los ríos británicos

Las invasiones biológicas pueden tener importantes repercusiones en la gestión y conservación de los ecosistemas fluviales si dan lugar a clasificaciones erróneas del estado de los cuerpos de agua. Sin embargo, el conocimiento de la sensibilidad de las herramientas de biomonitoreo frente a las especies invasoras en ríos, así como su influencia sobre las métricas taxonómicas y funcionales de la comunidad, es todavía limitado.

Esta investigación explora la respuesta de las comunidades de macroinvertebrados acuáticos a las invasiones biológicas utilizando índices taxonómicos y funcionales. Utilizando un conjunto de datos a largo plazo de ríos de Inglaterra (desde 2000 a 2019, con 5988 muestras), se examinó la respuesta de cuatro métricas de biomonitoreo (WHPT, WHPT-ASPT, LIFE, PSI) y dos índices funcionales (riqueza funcional y redundancia) antes y después del establecimiento de Dikerogammarus haemobaphes (Eichwald, 1841) (Crustacea: Gammaridae), un invasor reciente en los ríos de Inglaterra (primera cita en 2012). Se investigaron los efectos espaciales (a nivel nacional y de cuenca) y estacionales utilizando un diseño experimental "BACI" y modelos lineales mixtos.

Los resultados muestran que la invasión de $D$. haemobaphes provoca descensos significativos del índice WHPT y de las métricas de diversidad funcional, mientras que se observan patrones más sutiles en otras métricas. El análisis de los datos por cuencas (Trent y Thames) y por estación (primavera y otoño) identificó respuestas consistentes en gran medida. El establecimiento de D. haemobaphes dio lugar también a algunas modificaciones en la composición funcional de las comunidades, asociadas principalmente a los rasgos biológicos de voltinismo y formas de resistencia.

Estos resultados muestran que el establecimiento de poblaciones de D. haemobaphes puede considerarse como una presión significativa para las comunidades fluviales. Estos resultados tendrían implicaciones para el biomonitoreo y la gestión, ya que es posible que los efectos de la invasión no se detecten utilizando únicamente índices taxonómicos. Así, las métricas funcionales de la comunidad resultan de utilidad en la caracterización de los efectos de las especies invasoras, debiendo formar parte de la "caja de herramientas" utilizada para estudiar las invasiones biológicas en ríos. Esta investigación ilustra la necesidad de considerar, en sentido amplio, las amenazas que representan las especies invasoras sobre la integridad de los ecosistemas fluviales a largo plazo, así como la efícacia de las diferentes herramientas de biomonitoreo. 


\section{Introduction}

105 The biological invasion of freshwater bodies by non-native invasive species is recognised as a growing pressure (Strayer, 2010; Gallardo, Clavero, Sánchez \& Vilà, 2016) that may lead to biotic homogenization (Toussaint, Beauchard, Oberdorff, Brosse \& Villéger, 2014), affecting species interactions and food web architecture (Twardochleb, Olden \& Larson, 2013; Carbonell et al., 2017). Given the growing number of new invasive species globally (Seebens et al., 2017), the evaluation of their potential effects represents a major challenge for bioassessment science and aquatic ecology, with potential cascading effects for the management and conservation of freshwater systems if their presence leads to misclassification (e.g. Orendt, Schmitt, van Liefferinge, Wolfram \& Deckere, 2010). Invasive species may constitute significant threats to the integrity of aquatic ecosystems that existing biomonitoring tools were not designed to address and may fail to detect their effects or presence within a waterbody (MacNeil, Briffa, Leuven, Gell \& Selman, 2010; Vandekerkhove, Cardoso \& Boon, 2013; Guareschi \& Wood, 2019). Moreover, the integration of their presence and associated information into official biomonitoring and management frameworks has been applied heterogeneously internationally (Boon, Clarke \& Copp, 2020). Aquatic macroinvertebrates are essential components of freshwater ecosystems (Suter \& Cormier, 2015) and are currently among the most widely utilised indicators in freshwater biomonitoring by environmental agencies and legislators worldwide (Buss et al., 2015). Macroinvertebrate-based indices are usually based on the sensitivity of individual taxa to a specific pressure, such as organic pollution or flow stress, with taxa assigned sensitivity based on known / documented preferences (e.g. Hawkes, 1998; Extence, Balbi, Chadd, 1999). These scoring systems rarely recognize or integrate invasive invertebrate taxa, largely because their effect may be context-specific and the dynamics of their spread difficult to assess and integrate within legislation (Guareschi \& Wood, 2019). For example, Mathers et al. (2016) warned that care should be taken when interpreting routine taxonomic macroinvertebrate biomonitoring data where non-native crayfish were known to be present; and Vandekerkhove, Cardoso \& Boon (2013) advocated the need for optimization of methods for addressing the pressures exerted by invasive species. 
The use of taxonomic-based datasets and metrics is crucial for biological conservation and long-term studies in ecology, however on their own they limit the ability to transfer or compare methodologies and results between regions (Van den Brink et al., 2011). To address this issue, community functional measures based on codified organism traits (e.g. body morphology, trophic habits and life-history strategies) have been developed to provide functional metrics that are geographically generalisable. These community functional metrics are unaffected by regional species lists and advance understanding beyond traditional taxonomic approaches (e.g. Villéger, Mason \& Mouillot, 2008; Mouillot, Graham, Villéger, Mason \& Bellwood, 2013; Soria et al., 2020). Functional responses have been increasingly tested in bioassessment and primary ecological research (e.g. Mondy, Villeneuve, Archaimbault \& Usseglio-Polatera, 2012; Belmar et al., 2019), being recently identified as a promising approach for the assessment of impacts associated with biological invasion (Colin, Villéger, Wilkes, de Sostoa \& Maceda-Veiga, 2018; Mathers et al., 2020a), but to date rarely used (Flood, Duran, Barton, Mercado-Molina \& Trexler, 2020). To integrate environmental management and invasive species research better, wide-ranging studies considering multiple components of communities have been proposed (e.g. Matzek, Pujalet \& Cresci, 2015). Moreover, the implications of aquatic invasive species on both taxonomically derived biomonitoring tools and community-based functional metrics have not been widely explored using long-term datasets comprising both invaded and control sites (see Mathers et al. 2020a for a recent trait-based example). To address these research gaps, this study aimed to examine the consequences of a successful invasive species, Dikerogammarus haemobaphes (Eichwald, 1841) (Crustacea: Gammaridae) on river biomonitoring tool behaviour and macroinvertebrate community functional characteristics using a long-term dataset (20-years) from British rivers. Being a relatively new invader to the UK (2012), but rapidly expanding its range, the study of this species over the period 2000-2019 represents a timely opportunity to examine the process of biological invasion in rivers. Specifically, this study sought to determine if the performance of four taxonomic-based biomonitoring tools used by regulatory agencies for freshwater system assessments and two functional indices (functional richness and redundancy) were affected following the establishment of the invasive amphipod (pre- and postinvasion assessments). In addition, this provided an opportunity to explore changes in the 
macroinvertebrate functional composition following invasion by $D$. haemobaphes. Examination of this dataset at different spatial and seasonal scales would allow the identification of any shifts or changes to the results of biological indices and biomonitoring tools after the colonization of $D$. haemobaphes and facilitate an evaluation of the indirect ability of the tool(s) to detect any effects of the invasion on the wider freshwater macroinvertebrate community.

\section{Materials and Methods}

\subsection{Biological data}

Dikerogammarus haemobaphes, commonly known as "demon shrimp", is an example of successful invasive species originating from the Ponto Caspian region and now recorded in many European areas (Bacela-Spychalska \& van der Velde, 2013). The first British record of D. haemobaphes was in May 2012 from the River Severn (Aldridge, 2013) and it has subsequently spread rapidly, invading waterways throughout central England (Johns, Smith, Homann \& England, 2018). Data were obtained from the Environment Agency, the statutory regulator within England, which is responsible for monitoring and reporting the ecological quality and status of waterbodies. The dataset, considered in the analysis, comprised 5,988 samples from 259 lotic sampling sites ( 82 invaded sites and 177 control, details in Appendices S1 and S2 in Supporting information) across England, collected over a 20-year period (2000-2019 inclusive). For consistency, all 259 sites comprised at least 4 samples and were not subject to any other disturbance events (e.g. samples from pollution incidents) or contained other Dikerogammarus species. All benthic invertebrate samples were collected using a standard sampling protocol for river biomonitoring, comprising a 3-minute 'kicksample' using a standard pond-net (ISO 7828-1985) covering all available habitats in proportion to their occurrence, followed by a 1-minute hand search (RIVPACS Macro-invertebrate Sampling Protocol, available at http://www.eu-star.at/frameset.htm).

Given that $D$. haemobaphes was first recorded in 2012, data from control sites for that year were not included in the current analysis. Samples collected prior to $1^{\text {st }}$ January 2012 were considered "before" and data after $31^{\text {st }}$ December 2012 as "after" invasion (n. total=177). Invaded sample sites were 
classified into before and after invasion based on the date of the first record of $D$. haemobaphes in the dataset at the site. Given that the majority of the data could be ascribed to two river basins (River Thames and R. Trent), the analysis was undertaken at two spatial scales: national level (all data) and for individual basins (2,651 samples from the $\mathrm{R}$. Thames basin and 2,633 samples from the R. Trent basin). Assuming the potential effect of seasonality on macroinvertebrate occurrence (e.g. Mathers et al., 2016) analysis at the national level was also undertaken using spring (2,365 samples) and autumn datasets (2,291 samples) separately. These seasons are used routinely for biomonitoring purpose in UK rivers (UKTAG, 2014). Macroinvertebrate data were largely recorded at species level (60\% of the entire taxa, $\mathrm{n}=962$ ) and genus, while some Diptera larvae were resolved to family level and some taxa such as Hydracarina and Oligochaeta were recorded as such.

\subsection{Biomonitoring tools: taxonomic and functional indices}

Four standard taxonomic indices were calculated for each sample to obtain a comprehensive coverage of available biomonitoring tools: i) the Whalley, Hawkes, Paisley \& Trigg index (WHPT Total: abundance-based adaptation of the globally utilised BMWP index, UKTAG, 2014) which is derived from the sensitivity of invertebrate families to organic pollution but can be affected by other factors; ii) the WHPT Average Score Per-Taxon (total WHPT value divided by the number of scoring taxa, coded WHPT-ASPT; Paisley, Trigg \& Walley, 2014) which principally reflects organic pollution; iii) the Lotic Invertebrate index for Flow Evaluation (LIFE; Extence et al., 1999) which considers river flow and effects on instream communities; and iv) the Proportion of Sediment-sensitive Invertebrates (PSI; Extence et al., 2013), which provides a measure of community sensitivity to fine sediments deposition. All the above indices can be calculated using taxonomic data resolved to family level and are used by the Environment Agency to provide relative measures of lotic ecosystem conditions. The WHPT-ASPT is used, in conjunction with the number of WHPT scoring taxa, in the UK to characterise the ecological status of rivers in accordance with the requirements of the EU Water Framework Directive. The WHPT scoring system and other very similar approaches have been widely applied globally to characterise the ecological quality of flowing waterbodies (Buss et al., 2015; 
sensitivity lists and associated scoring systems and were specifically investigated because flow velocity, substrate composition and suspended sediment concentrations have been identified as potential abiotic parameters that may affect the distribution of Dikerogammarus species (Borza, Huber, Leitner, Remund \& Graf, 2017). Functional diversity responses were investigated through calculating two metrics: i) functional richness (FRich) and ii) functional redundancy (FRed) for each sample. Both indices have been specifically identified as being sensitive to anthropogenic pressures in riparian and fluvial habitats (Bruno, Gutiérrez-Cánovas, Sánchez-Fernández, Velasco \& Nilsson, 2016; Belmar et al., 2019). FRich is defined as the volume of functional multidimensional space occupied by all species in a community (following Villéger et al., 2008), while FRed reflects the relative resistance and resilience of an ecosystem to pressure (Hooper et al., 2005; McLean et al., 2019) and quantifies the degree to which species in a community share similar ecological features. FRed is calculated as the difference between taxonomic diversity (using the Gini-Simpson index) and functional diversity (using Rao's quadratic entropy) following Pillar et al. (2013). Both functional measures were characterized using the macroinvertebrate biological traits proposed by Tachet, Richoux, Bournaud \& Usseglio-Polatera (2010) and Schmidt-Kloiber and Hering (2015) at the genus level. Taxa resolved to species level were aggregated to genus to be consistent with current trait classifications while data resolved to family were assigned values based on the average for the genus. Genus-level information is widely considered suitable to study the functional diversity and response of riverine communities (e.g., Gutiérrez-Cánovas, Sánchez-Fernández, Velasco, Millán \& Bonada, 2015). This approach allowed the entire dataset covering 20 years to be utilized. Gower dissimilarity matrices (adapted for the fuzzy-coded traits, Pavoine, Vallet, Dufour, Gachet \& Daniel, 2009) using all the 11 biological traits (63 modalities, Appendix S3) were used to calculate FRich. To calculate FRed five "effect traits" (size, dispersal, mode of locomotion, food consumed and feeding habits) were selected based on the review of Schmera, Heino, Podani, Erós \& Dolédec (2017) and Hevia et al. (2017). An identical approach to measure both functional metrics was adopted by Bruno et al. (2019) and Laini et al. (2019) for alpine and temperate riverine community. However, to provide comprehensive coverage, functional redundancy considering all the biological traits was also calculated and inter-correlations among all measures examined. 


\subsection{Data analysis}

245 To estimate potential changes in the biomonitoring tools examined (taxonomic and functional), data were analysed in a Before-After Control-Impact (BACI) design framework. To achieve this, each sample was placed into one of four groups: (i) control-before invasion, (ii) control-after invasion, (iii) invaded-before invasion date and (iv) invaded-after invasion date. The use of control sites (in the same climatic and geographic areas and for the same time-period) provided a complete BACI study design that is considered optimal when attempting to isolate the effect of an impact from natural variability (Christie et al., 2019). In this instance the potential impact considered was before and after the establishment of a new invasive species, D. haemobaphes. BACI analysis with a significant interaction (Before-After) * (Control-Impact) would indicate that following the establishment of $D$. haemobaphes population there had been an effect on the community measures at invaded sites. To determine the potential effects of the arrival of Dikerogamamrus haemobaphes on biomonitoring tools and functional metrics, they were analysed within a linear mixed models' framework to avoid pseudoreplication (LMM; package "ImerTest" Kuznetsova, Brockhoff \& Christensen, 2017). LMMs are powerful tools for analysing complex datasets with multiple or clustered observations (Schielzeth et al., 2020) and were repeated at different spatial scales and seasons considering the interaction $(\mathrm{BA} * \mathrm{CI})$ as a fixed factor while sampling sites and year as random factors. All indices were standardised (subtracting the mean and dividing by the standard deviation) to facilitate comparison of the potential changes after the arrival of the invasive species. All models were validated by visually checking the graphical distribution of residuals for normality and homoscedasticity (Zuur et al., 2009). Correlations (Spearman rank correlations) among all indices were also investigated to assess their associations and inter-relatedness. To explore for potential differences in the functional structure of invertebrate communities, a fuzzy principal component analysis (FPCA, Chevenet, Dolédec \& Chessel, 1994; Bruno et al., 2019) was performed on the Community-level Weighted Means matrix (CWM). CWM matrix with the proportion of each trait character from each sampling site was obtained by crossing the "taxon $\mathrm{x}$ traits" and "taxon x site" matrices. Squared-root transformation was applied on abundance data prior 
271 to the calculation of the CWM matrix. Ordinations were performed separately for each dataset

272 (national, basin, season scale) to explore differences in functional trait compositions between BACI

273 levels using the first two axes. This enabled the potential shift in community functional composition to be identified (via the movements in centroid location before and after invasion for both the control and impact groups) in addition to changes in the size or shape of the functional space (via the convex hull - the minimum area enclosing all functional community values). Given the unbalanced number of samples between BACI levels, randomization samples were selected for each group using the least abundant sample group as the threshold ( $>500$ samples at national level and $>100$ at basin and seasonal level). The consistency of the outputs was assessed by testing changes in the slope of the connecting line between pairs of centroids and their distance over 1,000 simulations. All statistical analyses were performed using R statistical software v. 3.6.2 (R Core Team, 2019) and scripts used to calculate functional indices are available at https://github.com/alexology/biomonitoR.

\section{Results}

Taxonomic and functional indices were significantly but weakly correlated (maximum Spearman correlation coefficient was 0.37 between WHPT and FRich), indicating that the different indices represented distinct macroinvertebrate community characteristics. In contrast, the two measures of Functional redundancy (using all traits and the effects traits alone) were highly correlated $(r=0.91, p-$ value $<0.001$ ) and as a result only the one using effects traits were considered in subsequent analyses. A full list of the cross-correlation results among taxonomic and functional indices are presented in Appendix S4.

\subsection{Implications at national level}

A total of 5,988 samples comprising more than 8 million individual macroinvertebrate specimens were included in the analysis. The outputs from linear mixed models indicated significant changes in 4 of the 6 metrics considered ( 2 taxonomic and 2 functional indices) following the invasion of 
contrasting patterns between control and invaded sites with a significant reduction observed at invaded sites compared to stable or marginal increases at control sites (Figure 1). PSI displayed significant changes with limited or no increase after the arrival of the species compared to control samples (Figure 1). LIFE and WHPT-ASPT did not display significant changes.

When the two main sampling seasons were considered separately similar patterns and trends were recorded especially for autumn samples (Table 1, Appendix S5) when compared to 'all samples' at the national level. Significant differences (with reductions in index values at invaded sites) were observed between the control and invaded sites for WHPT, FRich and Fred, while the output for WHPT-ASPT, PSI and LIFE displayed similar trends and no significant changes.

The pattern for the spring sampling season was also comparable to the autumn, although the statistical significance was slightly reduced. Significantly different trends were recorded for WHPT and FRich (lower values at invaded sites), while the response for Functional redundancy was marginally significant ( $\mathrm{p}=0.05$, Table 1 , Appendix S6).

Even though the general shape and size of the four functional composition plots were similar for each level at national scale, the FPCA ordination plots revealed some shifts when comparing the centroids of invaded and control sites on the first two axis; explaining $58.7 \%$ of the total variability (Figure 4). For the post invasion time period, samples from the control period migrated along the first axis (horizontally), primarily associated with "reproduction" (e.g. ovoviviparity) and "life cycle duration" characteristics. The centroids for the invaded samples shifted vertically on the second axis following the arrival of $D$. haemobaphes. The second axis was primarily associated with "resistance form" traits (e.g. lack of resistant life stage) and "number of life-cycles per year" (e.g. multi-voltinism). Trends and the associated traits were broadly comparable for the spring dataset (Figure 5, autumn dataset plots available in Appendix S7). The consistency of change in distance and slope between centroids (before and after of invaded and control samples) are presented in Appendix S8; and differences in slope results were confirmed via the randomization analysis at the national and seasonal levels.

\subsection{Implications at regional level}


The general patterns recorded for the River Thames and R. Trent basins were comparable and consistent with the results recorded at the national scale, with significant changes of WHPT, FRich and FRed in both river basins after the arrival of D. haemobaphes. Within the R. Trent basin (Figure 2, Appendix S9), the most marked reductions (at the invaded sites) were observed for WHPT, functional richness and functional redundancy, while LIFE, WHPT-ASPT and PSI displayed more subtle patterns. Similar patterns were recorded for the R. Thames basin (Figure 3, Appendix S9), where the most marked changes were observed for WHPT, PSI and both functional measures. Focussing on functional composition, in both river basins the invaded site centroids migrated on the second axis (associated with multi-voltinism and resistance life form / stages) when compared to control sites that migrated along the first axis (Appendices S10 and S11, first two axes explained $>50 \%$ of the total variance in all instances). However, the centroid shifts were not always significant after randomization as there was some overlap in slope confidence intervals for both datasets. Interestingly, in the R. Trent basin $100 \%$ of the randomizations (1000 out of 1000) displayed greater distance between the centroids for the before and after periods for the invaded site samples (S8).

\section{Discussion}

The use of long-term datasets to enable the detection of temporal change has been increasingly advocated (e.g. Dafforn et al., 2016), and data from routine biomonitoring activities may provide appropriate long-term, high quality, standardized datasets for analysis of changes in the aquatic environment. For example, Vaughan and Ormerod (2012) identified an improving trend of water and biological quality over the period 1991-2008 using biomonitoring data for British rivers. The results of our long-term analysis (2000-2019) identify a similar pattern, with an increase or constant trend for most biological metrics when only control samples were considered. However, when the overall BACI dataset is considered, our results provide insights into how river communities are affected by a new invader as changes to both taxonomic metrics and functioning of instream macroinvertebrate communities were identified. Although we cannot exclude the potential interactions and cumulative effects of other historically recorded non-native species already present in British rivers (e.g. 
years around the date of the first record) may limit this influence. The results of this research support the fact that $D$. haemobaphes should be considered a significant threat to rivers it invades given the changes and reductions we observed for multiple types of indices (based on taxonomic and functional information, and on both presence and abundance data) and across spatial scales and seasons. This reinforces the need for specific research (e.g. periodic monitoring of population dynamic) and management activities (e.g. biosecurity protocols) focussed on invasive species. The effects recorded are probably related to the functional characteristics of successful invaders like D.haemobaphes including its flexible feeding habits, successful predatory behaviour (including intraguild predation), high fecundity and competition for resources with other species; or a combination of all these factors (Kinzler, Kley, Mayer, Waloszek \& Maier, 2009; Bacela-Spychalska \& van der Velde, 2013; Gallardo \& Aldridge, 2013a; Constable \& Birkby, 2016). Moreover, recent research has also indicated how D. haemobaphes may carry pathogens and parasites into its invasive range (e.g. Cucumispora ornate) that potentially threaten native species populations (Bojko et al., 2019). Great Britain has become increasingly affected by aquatic invertebrate invaders originating from the Ponto Caspian region (Gallardo \& Aldridge, 2013a; Gallardo \& Aldridge, 2013b; Gallardo \& Aldridge, 2015). The extensive network of river channels and canals in the UK, coupled with inter-basin water transfers, have been recognized as migratory pathways that may have directly facilitated the internal dispersal of D. haemobaphes (Johns et al., 2018) and other invasive taxa (Gallardo \& Aldridge, 2018).

Our research facilitates a preliminary evaluation of the ability of current indices and tools to detect the effect of the invasion on the wider freshwater community. The performance of the Whalley, Hawkes, Paisley \& Trigg index (WHPT - Paisley et al., 2014) in relation to invasive species has been presented for the first time in this research and it was shown to be particularly sensitive at all scales (national level, basin level and season) to the invasion of D. haemobaphes. A similar level of sensitivity was displayed by both functional metrics (with highly significant differences being recorded in 4 of the 5 sets of analysis). These results support those of Ćuk et al. (2019) who reported a negative effect of multiple invasive species on riverine biological monitoring tools, including the BMWP score, in Croatian rivers. Similarly, MacNeil et al. (2013) demonstrated how invasion by the co-generic Dikerogammarus villosus affected two macroinvertebrate-based indices, the MMIF (Multimetric 

(Hawkes, 1998) in Belgium.

It is particularly interesting to note that the response of the WHPT score and WHPT-ASPT, the latter being used directly for WFD ecological assessment in British rivers, displayed different trends despite being correlated with each other. The WHPT-ASPT displayed marginally significant changes at basin level (but not a reduction) at sites invaded by D. haemobaphes compared to control sites, although the trends were comparable. These results display a similar pattern to those of Mathers et al. (2016), who demonstrated that ASPT scores (derived from BMWP, Armitage, Moss, Wright \& Furse, 1983) did not significantly change following invasion of signal crayfish (Pacifastacus leniusculus). Similarly, the Spanish adaptation of the index, IASPT (Iberian ASPT - Alba-Tercedor et al., 2002) has also been shown to be relatively insensitive to the presence of rare taxa (Guareschi et al., 2017) that may occur during the early stages of colonisation by non-native taxa.

These different patterns may primarily reflect the ASPT calculation method (average value of all scoring taxa), but also to the fact that it was originally designed to reflect taxa sensitivity to organic pollution (Sandin \& Hering, 2004). The decline recorded in total WHPT score, but not WHPT-ASPT, may indicate that a pressure other than organic pollution was present. The BACI analysis indicates that the decline was most likely due to the invasion of $D$. haemobaphes. These results also highlight the need to recognise the purpose for which the individual tools were originally designed. Their appropriate use, ideally in combination (taxonomically based and community functional measures) may provide a greater understanding of the multiple pressures present in a waterbody.

The observed trends for the Proportion of Sediment-sensitive Invertebrates (PSI) and the Loticinvertebrate Index for Flow Evaluation (LIFE) suggest that these indices are less sensitive to the establishment of $D$. haemobaphes populations than the other indices examined. In contrast, Mathers et al. (2016) demonstrated that abundance weighted biomonitoring tools such as LIFE and PSI were subject to significant inflation following Pacifastacus leniusculus invasion and its selective predation on low scoring taxa. When considered together, these results demonstrate the need for care when choosing and interpreting biomonitoring tools as the effects may also vary reflecting the individual characteristics of the invasive species. When compared to P. leniusculus, D. haemobaphes did not 
show a marked seasonal variability in the effects on the wider community (except for functional redundancy measures), suggesting a constant pressure on riverine systems throughout the year. The response of functional indices following the invasion of $D$. haemobaphes indicated a consistent significant decreasing trend of both measures (at both the seasonal and spatial scales) at invaded sites, compared to relatively stable or slightly increasing values at control sites. Similarly, Michelan, Thomaz, Mormul \& Carvalho (2010) demonstrated how plant community functional richness was significantly reduced as the biomass of Urochloa subquadripara (an invasive macrophyte) increased in Brazilian waterbodies. In addition, Milardi, Gavioli, Soininen \& Castaldelli (2019) demonstrated how alien species invasions may undermine regional functional diversity in Mediterranean stream fish communities. Focussing on British rivers, Mathers et al. (2020b) recently reported that the functional properties (e.g. richness) of macroinvertebrate communities can be negatively affected by signal crayfish invasion (but with differences at the regional level). This highlights the importance of considering community functional measures alongside other indices to facilitate understanding and interpretation of biological communities' results (e.g. Perez Rocha et al., 2019) also in aquatic biological invasions.

When the effect of community functional characteristics (at invaded sites) are considered alongside the reduction in WHPT scores temporally, it suggests that the arrival and establishment of $D$. haemobaphes in British rivers should be considered a long-term sustained pressure affecting riverine macroinvertebrate community structure and functioning. A reduction of functional richness may affect river ecosystem functioning via a reduction in productivity, nutrient cycling and litter decomposition. Moreover, the reduction in community functional redundancy may also reflect impairment of ecosystems resilience and sensitivity to disturbances (Angeler et al., 2016; McLean et al., 2019) and may indicate ecosystem and community vulnerability to future disturbances. Instream functional measures (richness and redundancy) were particularly sensitive to biological invasion in our study and may be valuable tools in facilitating the detection of the establishment of an invasive species population, which could be used as part of a "toolbox" for the assessment of biological invasion of aquatic ecosystems. However, further research is recommended to examine the effects of multiple invasive species occurring at the same site, and in particular their effects on 
community functioning and biological metrics so that specific indices that focus on biological invasions can be developed (see a an attempt in Arbaciauskas et al., 2008; Gallardo \& Aldridge, 2013b) and better integrated into national and international legislation.

The analysis of functional trait composition appeared to identify more subtle trends than those obtained from specific functional metrics. Although the shifts following the establishment of the invading species appeared quantitatively limited, it is important to note that the changes recorded at invaded sites typically contrasted (i.e. different direction of change) or were characterised by different magnitudes of change (i.e. different distance between centroids) when compared to control sites. These significant shifts were generally associated with multi-voltinism (number of cycles per year) at the national and seasonal scale, while more subtle patterns were observed at the individual basin level. Changes to voltinism patterns have been identified as a response to different stressors in both aquatic (Belmar et al., 2019) and terrestrial invertebrates (Altermatt, 2009). Similarly, when considering signal crayfish in UK, Mathers et al. (2020b) reported that taxa with one brood per year and/or that take over a year to complete a life cycle were negatively affected following invasions in some regions. Considering the successful invasive characteristics displayed by $D$. haemobaphes, its expanding geographic distribution (numerous European countries) and the biomonitoring metrics applied, the results have widescale relevance for other invasive species and environmental contexts (e.g. freshwater ecologists, conservationists, environmental agencies, private consultancies). Our results provide an important starting point for the development of biological monitoring measures designed to detect the presence and impacts of invasive species. The development of such tools would advance global scientific research in the field and benefit numerous stakeholders providing a more complete understanding of the process and effects of biological invasion within river ecosystems.

\section{Acknowledgment}

S. Guareschi was supported by a Royal Society-Newton International Fellowship at Loughborough

463 University (NIF\R1\180346). The authors would like to express their gratitude towards the various 464 Environment Agency teams for collecting, preparing and extracting the data from the BIOSYS dataset, 465 especially Carole Fitzpatrick. The views expressed in this paper are those of the authors and not 
necessarily those of the Environment Agency of England. Mark Szegner is gratefully acknowledged for the preparation of Figure S2. The authors thank and acknowledge the insightful and constructive comments of two anonymous reviewers, the associate editor and editor which have improved the manuscript.

470

\section{Authors' Contributions}

472 SG and PJW conceived the idea and designed methodology; JE, TJ, MW provided the raw data; SG and AL analysed the data; JE, TJ, MW, PJW provided interpretations of results from a management perspective; SG led the writing of the manuscript. All authors contributed critically to the drafts and gave final approval for publication.

\section{Data availability statement}

All site details and biological data can be obtained freely from the Environment Agency "Ecology and Fish Data Explorer" at https:/environment.data.gov.uk/ecology-fish/ selecting "invertebrates". To obtain the data - specify the period required and select the geographic area on the map and input site codes (SITE_ID) found in first column of Appendix S1.

\section{References}

485

486

487

488

489

490

491

492

493

494

495

496

497

498

499 500

Alba-Tercedor, J., Jáimez-Cuellar, P., Álvarez, M., Avilés, J., Bonada, N., Casas, J., ..., ZamoraMuñoz, C. (2002). Caracterización del estado ecológico de ríos mediterráneos ibéricos mediante el índice IBMWP (antes BMWP'). Limnetica, 21, 175-186.

Aldridge, D.C. (2013). GB non-native organism rapid risk assessment for Dikerogammarus haemobaphes (Eichwald, 1841). http://www.nonnativespecies.org/downloadDocument.cfm?id=870. Accessed 10 June 2019

Angeler, D.G., Allen, C.R., Barichievy, C., Eason, T., Garmestani, A.S., Graham, N.A., ... Sundstrom, S.M. (2016). Management applications of discontinuity theory. Journal of Applied Ecology, 53, 688-698. https://doi.org/10.1111/1365-2664.12494

Arbaciauskas, K., Semenchenko, V., Grabowski, M., Leuven, R.S.E.W., Paunović, M., Son, M.O., ... Panov V.E. (2008). Assessment of biocontamination of benthic macroinvertebrate communities in European inland waterways. Aquatic Invasions 3: 211-230. http://doi.org/10.3391/ai.2008.3.2.12 
502 Armitage, P.D., Moss, D., Wright, J.F. \& Furse, M.T. (1983). The performance of a new biological

503 water quality score system based on macroinvertebrates over a wide range of unpolluted runningwater sites. Water Research, 17, 333-347. https://doi.org/10.1016/0043-1354(83)90188-4

505

Bacela-Spychalska, K. \& van der Velde, G. (2013). There is more than one 'killer shrimp': trophic positions and predatory abilities of invasive amphipods of Ponto-Caspian origin. Freshwater Biology 58, 730-741. https://doi.org/10.1111/fwb.12078

509

Belmar, O., Bruno, D., Guareschi, S., Mellado-Díaz, A., Millán, A. \& Velasco, J. (2019). Functional responses of aquatic macroinvertebrates to flow regulation are shaped by natural flow intermittence in Mediterranean streams. Freshwater Biology, 64, 1064-1077. https://doi.org/10.1111/fwb.13289

Bojko, J., Stentiford, G.D., Stebbing, P.D., Hassall, C., Deacon, A., Cargill, B., Pile, B. \& Dunn, A.M. (2019). Pathogens of Dikerogammarus haemobaphes regulate host activity and survival, but also threaten native amphipod populations in the UK. Diseases of Aquatic Organisms, 136, 63-78. https://doi.org/10.3354/dao03195

Boon, P.J., Clarke, S.A. \& Copp, G.H. (2020). Alien species and the EU Water Framework Directive: a comparative assessment of European approaches. Biological Invasions, 22, 1497-1512.

Borza, P., Huber, T., Leitner, P., Remund, N. \& Graf, W. (2017). Current velocity shapes co-existence patterns among invasive Dikerogammarus species. Freshwater Biology 62, 317-3 328.

Bruno, D., Gutiérrez-Cánovas, C., Sánchez-Fernández, D., Velasco, J. \& Nilsson, C. (2016). Impacts of environmental filters on functional redundancy in riparian vegetation. Journal of Applied Ecology, 53, 846-855. https://doi.org/10.1111/1365-2664.12619 catchments. Global Change Biology, 25, 1612-1628. https://doi.org/10.1111/gcb.14581 
programs. Environmental Monitoring and Assessment, 187, 4132. https://doi:10.1007/s10661-014$\underline{4132-8}$

Carbonell, J.A., Velasco, J., Millán, A., Green, A.J., Coccia, C., Guareschi, S. \& Gutiérrez-Cánovas, C. (2017). Biological invasion modifies the co-occurrence patterns of insects along a stress gradient. Functional Ecology, 31(10), 1957-1968. https://doi.org/10.1111/1365-2435.12884

Chevenet, F., Dolédec, S., \& Chessel, D. (1994). A fuzzy coding approach for the analysis of longterm ecological data. Freshwater Biology, 31(3), 295-309. https://doi.org/10.1111/j.13652427.1994.tb01742.x

Christie, A.P., Amano, T., Martin, P.A., Shackelford, G.E., Simmons, B.I. \& Sutherland, W.J. (2019). Simple study designs in ecology produce inaccurate estimates of biodiversity responses. Journal of Applied Ecology, 56, 2742-2754. https://doi.org/10.1111/1365-2664.13499

Colin, N., Villéger, S., Wilkes, M., de Sostoa, A. \& Maceda-Veiga, A. (2018). Functional diversity measures revealed impacts of non-native species and habitat degradation on species-poor freshwater fish assemblages. Science of the Total Environment, 625, 861-871.

https://doi.org/10.1016/j.scitotenv.2017.12.316

Constable, D. \& Birkby, N.J. (2016). The impact of the invasive amphipod Dikerogammarus haemobaphes on leaf litter processing in UK rivers. Aquatic Ecology, 50, 273-281. https://doi.org/10.1007/s10452-016-9574-3

Ćuk, R., Miliša, M., Atanacković, A., Dekić, S., Blažeković, L. \& Žganec, K. (2019).

Biocontamination of benthic macroinvertebrate assemblages in Croatian major rivers and effects on ecological quality assessment. Knowledge \& Management of Aquatic Ecosystems, 420, 11. https://doi.org/10.1051/kmae/2019003

Dafforn, K.A., Johnston, E.L., Ferguson, A., Humphrey, C.L., Monk, W., Nichols, S.J., ..,, Baird, D.J. (2016). Big data opportunities and challenges for assessing multiple stressors across scales in aquatic ecosystems. Marine and Freshwater Research, 67, 393-413. https://doi.org/10.1071/MF15108

Extence, C.A., Balbi, D.M. \& Chadd, R.P. (1999). River flow indexing using British benthic macroinvertebrates: a framework for setting hydroecological objectives. Regulated Rivers: Research \& Management 15, 543-574. https://doi.org/10.1002/(SICI)1099-1646(199911/12)15:6<545::AID$\underline{\text { RRR561>3.0.CO;2-W }}$ 
575 Extence, C.A., Chadd, R.P., England, J., Dunbar, M.J., Wood, P.J. \& Taylor, E.D. (2013). The

576 assessment of fine sediment accumulation in rivers using macro-invertebrate community response.

577 River Research and Applications, 29, 17-55. https://doi.org/10.1002/rra.1569

578

579 Flood, P.J., Duran, A., Barton, M., Mercado-Molina, A.E. \& Trexler, J.C. (2020). Invasion impacts on

580 functions and services of aquatic ecosystems. Hydrobiologia, 847, 1571-1586.

581 https://doi.org/10.1007/s10750-020-04211-3p.1-16.

582

583 Gabriels W., Lock K., De Pauw N. \& Goethals, P.L.M. (2010). Multimetric Macroinvertebrate Index

584 Flanders (MMIF) for biological assessment of rivers and lakes in Flanders (Belgium). Limnologica,

585 40, 199-207. https://doi.org/10.1016/j.limno.2009.10.001

586

587 Gallardo, B. \& Aldridge, D.C. (2013a). Review of the ecological impact and invasion potential of 588 Ponto Caspian invaders in Great Britain. Cambridge Environmental Consulting, Technical Report, 589 pp.130.

590

591 Gallardo, B. \& Aldridge, D.C. (2013b). The 'dirty dozen': socio-economic factors amplify the 592 invasion potential of 12 high-risk aquatic invasive species in Great Britain and Ireland. Journal of 593 Applied Ecology, 50, 757-766. https://doi.org/10.1111/1365-2664.12079

594

595 Gallardo, B. \& Aldridge, D.C. (2015). Is Great Britain heading for a Ponto Caspian invasional 596 meltdown? Journal of Applied Ecology, 52, 41-49. https://doi.org/10.1111/1365-2664.12348

597

598 Gallardo, B., Clavero, M., Sánchez, M.I. \& Vilà, M. (2016). Global ecological impacts of invasive 599 species in aquatic ecosystems. Global Change Biology, 22, 151-163.

600 https://doi.org/10.1111/gcb.13004

601

602 Gallardo, B. \& Aldridge, D.C. (2018). Inter-basin water transfers and the expansion of aquatic 603 invasive species. Water Research, 143, 282-291. https://doi.org/10.1016/j.watres.2018.06.056 604

605 Guareschi, S., Laini, A. \& Sánchez-Montoya, M.M. (2017). How do low-abundance taxa affect river 606 biomonitoring? Exploring the response of different macroinvertebrate-based indices. Journal of 607 Limnology 76, 9-20. https://doi.org/10.4081/jlimnol.2016.1516 
Guareschi, S. \& Wood, P.J. (2019). Taxonomic changes and non-native species: An overview of constraints and new challenges for macroinvertebrate-based indices calculation in river ecosystems. Science of the Total Environment, 660, 40 - 46. https://doi.org/10.1016/j.scitotenv.2019.01.008

Gutiérrez-Cánovas, C., Sánchez-Fernández, D., Velasco, J., Millán, A. \& Bonada, N. (2015). Similarity in the difference: Changes in community functional features along natural and anthropogenic stress gradients. Ecology 2015, 96, 2458-2466. https://doi.org/10.1890/14-1447.1

Hawkes, H.A. (1998). Origin and development of the biological monitoring working party score system. Water Research, 32, 964-968. https://doi.org/10.1016/S0043-1354(97)00275-3

Hevia, V., Martín-López, B., Palomo, S., García-Llorente, M., de Bello, F., \& González, J.A. (2017). Trait-based approaches to analyze links between the drivers of change and ecosystem services: Synthesizing existing evidence and future challenges. Ecology and Evolution, 7, 831-844. https://doi.org/10.1002/ece3.2692

Hooper, D.U., Chapin, F.S.I.I.I., Ewel, J.J., Hector, A., Inchausti, P., Lavorel, S., ..., Wardle, D.A. (2005). Effects of biodiversity on ecosystem functioning: a consensus of current knowledge. Ecological Monographs, 75, 3-35. https://doi.org/10.1890/04-0922

Johns, T., Smith, D.C., Homann, S. \& England, J.A. (2018). Time-series analysis of a native and a non-native amphipod shrimp in two English rivers. BioInvasions Record, 7(2), 101-110.

https://doi.org/10.3391/bir.2018.7.2.01

Kinzler, W., Kley, A., Mayer, G., Waloszek, D., \& Maier, G. (2009). Mutual predation between and cannibalism within several freshwater gammarids: Dikerogammarus villosus versus one native and three invasives. Aquatic Ecology, 43, 457-464. https://doi.org/10.1007/s10452-008-9206-7

Kuznetsova, A., Brockhoff, P.B. \& Christensen, R.H.B. (2017). LmerTest package: Tests in linear mixed effects models. J. Stat. Softw. 82, 1-26. https://doi.org/10.18637/jss.v082.i13

Laini, A., Viaroli, P., Bolpagni, R., Cancellario, T., Racchetti, E. \& Guareschi, S. (2019). Taxonomic and functional responses of benthic macroinvertebrate communities to hydrological and water quality variations in a heavily regulated river. Water, 11, 1478. https://doi.org/10.3390/w11071478

MacNeil, C., Briffa, M., Leuven, R.S., Gell, F.R. \& Selman, R. (2010). An appraisal of a biocontamination assessment method for freshwater macroinvertebrate assemblages; a practical way 

shrimp" (Dikerogammarus villosus) on macroinvertebrate assemblages and biomonitoring indices. Freshwater Biology, 58, 171-182. https://doi.org/10.1111/fwb.12048

652

Mathers, K.L., Chadd, R.P., Extence, C.A., Rice, S.P. \& Wood, P.J. (2016). The implications of an invasive species on the reliability of macroinvertebrate biomonitoring tools used in freshwater ecological assessments. Ecological Indicators, 63, 23-28.

656

https://doi.org/10.1016/j.ecolind.2015.11.051

657

Mathers, K.L., White, J.C., Guareschi, S., Hill, M.J., Heino, J. \& Chadd, R. (2020a). Invasive crayfish

659 alter the long-term functional biodiversity of lotic macroinvertebrate communities. Functional

660 Ecology https://doi.org/10.1111/1365-2435.13644

661

662

Mathers, K.L., White, J.C., Fornaroli, R. \& Chadd, R. (2020b). Flow regimes control the establishment of invasive crayfish and alter their effects on lotic macroinvertebrate communities. Journal of Applied Ecology. https://doi.org/10.1111/1365-2664.13584

665

Matzek, V., Pujalet, M. \& Cresci, S. (2015). What managers want from invasive species research 667 versus what they get. Conservation Letters, 8(1), 33-40. https://doi.org/10.1111/conl.12119

668

McLean, M., Auber, A., Graham, N. A. J., Houk, P., Villéger, S., Violle, C., ..., Mouillot, D. (2019). macrophyte (tropical signalgrass) on native plant community composition, species richness and functional diversity. Freshwater Biology, 55, 1315-1326. https://doi.org/10.1111/j.1365regional functional diversity of freshwater fish. Scientific Reports, 9(1), 1-10. 
682

683

684

685

686

687

688

689

690

691

692

693

694

695

696

697

698

699

700

701

702

703

704

705

706

707

708

709

710

711

712

713

714

715

716

717

718

Mondy, C.P., Villeneuve, B., Archaimbault, V. \& Usseglio-Polatera, P. (2012). A new

macroinvertebrate-based multimetric index (I2M2) to evaluate ecological quality of French wadeable streams fulfilling the WFD demands: a taxonomical and trait approach. Ecological Indicators 18, 452467. https://doi.org/10.1016/j.ecolind.2011.12.013

Mouillot, D., Graham, N.A., Villéger, S., Mason, N.W. \& Bellwood, D.R. (2013). A functional approach reveals community responses to disturbances. Trends in Ecology \& Evolution, 28, 167-177. https://doi.org/10.1016/j.tree.2012.10.004

Orendt, C., Schmitt, C., van Liefferinge, C., Wolfram, G. \& de Deckere, E. (2010). Include or exclude? A review on the role and suitability of aquatic invertebrate neozoa as indicators in biological assessment with special respect to fresh and brackish European waters. Biological invasions, 12(1), 265-283. https://doi.org/10.1007/s10530-009-9448-x

Paisley, M.F., Trigg, D.J. \& Walley, W.J. (2014). Revision of the biological monitoring working party (BMWP) score system: derivation of present-only and abundance-related scores from field data. River Research and Applications, 30, 887-904. https://doi.org/10.1002/rra.2686

Pavoine S., Vallet J., Dufour A.B., Gachet S. \& Daniel H. (2009) On the challenge of treating various types of variables: application for improving the measurement of functional diversity. Oikos, 118, 391-402. https://doi.org/10.1111/j.1600-0706.2008.16668.x

Perez Rocha, M., Bini, L.M., Grönroos, M., Hjort, J., Lindholm, M., Karjalainen, S.M., Tolonen, K.E. \& Heino, J. (2019). Correlates of different facets and components of beta diversity in stream organisms. Oecologia, 191(4), 919-929. https://doi.org/10.1007/s00442-019-04535-5

Pillar, V.D., Blanco, C.C., Müller, S.C., Sosinski, E.E., Joner, F. \& Duarte, L.D.S. (2013). Functional redundancy and stability in plant communities. Journal of Vegetation Science, 24, 963-974.

https://doi.org/10.1111/jvs.12047

R Core Team (2019). R: A language and environment for statistical computing. R Foundation for Statistical Computing, Vienna, Austria. URL https://www.R-project.org/.

Sandin, L. \& Hering, D. (2004). Comparing macroinvertebrate indices to detect organic pollution across Europe: a contribution to the EC Water Framework Directive intercalibration. Hydrobiologia, 1(516), 55-68. https://doi.org/10.1023/B:HYDR.0000025258.63416.11 
Schielzeth, H., Dingemanse, N. J., Nakagawa, S., Westneat, D. F., Allegue, H., Teplitsky, C., ... Araya-Ajoy, Y. G. (2020). Robustness of linear mixed-effects models to violations of distributional assumptions. Methods in Ecology and Evolution, 0-3. https://doi.org/10.1111/2041-210x.13434

Schmera, D., Heino, J., Podani, J., Erós, T. \& Dolédec, S. (2017). Functional diversity: A review of methodology and current knowledge in freshwater macroinvertebrate research. Hydrobiologia, 787, 27-44. https://doi.org/10.1007/s10750-016-2974-5

Schmidt-Kloiber, A. \& Hering, D. (2015). www. freshwaterecology. info-An online tool that unifies, standardises and codifies more than 20,000 European freshwater organisms and their ecological preferences. Ecological Indicators, 53, 271-282. https://doi.org/10.1016/j.ecolind.2015.02.007

Seebens, H., Blackburn, T.M., Dyer, E.E., Genovesi, P., Hulme, P.E., Jeschke, J.M., .., Essl, F., (2017). No saturation in the accumulation of alien species worldwide. Nature communications 8 : 14435. https://doi.org/10.1038/ncomms14435

Soria, M., Gutiérrez-Cánovas, C., Bonada, N., Acosta, R., Rodríguez-Lozano, P., Fortuño, P., ... Llorens, P. (2020). Natural disturbances can produce misleading bioassessment results: Identifying metrics to detect anthropogenic impacts in intermittent rivers. Journal of Applied Ecology, 57, $283-$ 295. https://doi.org/10.1111/1365-2664.13538

Strayer, D.L. (2010). Alien species in fresh waters: ecological effects, interactions with other stressors, and prospects for the future. Freshwater Biology 55, 152-174.

https://doi.org/10.1111/j.1365-2427.2009.02380.x

Suter, G.W. \& Cormier, S.M. (2015). Why care about aquatic insects: Uses, benefits, and services. Integrated environmental assessment and management, 11(2), 188-194.

https://doi.org/10.1002/ieam.1600

Tachet, H., Bournaud, M., Richoux, P., \& Usseglio-Polatera, P. (2010). Invertébrés d'eau douce: Systématique, Biologie, Écologie. Paris, France: CNRS Editions. 607 pp.

Toussaint, A., Beauchard, O., Oberdorff, T., Brosse, S. \& Villéger, S. (2014). Historical assemblage distinctiveness and the introduction of widespread non-native species explain worldwide changes in freshwater fish taxonomic dissimilarity. Global Ecology and Biogeography, 23, 574-584. https://doi.org/10.1111/geb.12141 
Twardochleb, L.A., Olden, J.D. \& Larson, E.R. (2013). A global meta-analysis of the ecological impacts of nonnative crayfish. Freshwater Science, 32(4), 1367-1382. https://doi.org/10.1899/12203.1

UKTAG (2014). UKTAG river assessment method, benthic invertebrate fauna. Invertebrates General Degradation: Whalley, Hawkes, Paisley \& Trigg WHPT Metric in River Invertebrate Classification Tool RICT Online Available from:

http://www.wfduk.org/sites/default/files/Media/Characterisation\%20of\%20the $\% 20$ water\%20environ ment/Biological\%20Method\%20Statements/River\%20Invertebrates\%20WHPT\%20UKTAG\%20Met hod\%20Statement.pdf Accessed date: 2 June 2019.

Van den Brink, P.J., Alexander, A.C., Desrosiers, M., Goedkoop, W., Goethals, P.L., Liess, M. \& Dyer, S.D. (2011). Traits-based approaches in bioassessment and ecological risk assessment: Strengths, weaknesses, opportunities and threats. Integrated environmental assessment and management, 7(2), 198-208. https://doi.org/10.1002/ieam.109

Vandekerkhove, J., Cardoso, A.C. \& Boon, P.J. (2013). Is there a need for a more explicit accounting of invasive alien species under the Water Framework Directive? Management of Biological Invasions, 4, p.25-36. http://dx.doi.org/10.3391/mbi.2013.4.1.04

Vaughan, I.P. \& Ormerod, S.J. (2012). Large-scale, long-term trends in British river macroinvertebrates. Global Change Biology, 18, 2184-2194. https://doi.org/10.1111/j.1365$\underline{2486.2012 .02662 . \mathrm{x}}$

Villéger, S., Mason, N.W.H. \& Mouillot, D. (2008). New Multidimensional Functional Diversity Indices for a Multifaceted Framework in Functional Ecology. Ecology, 89, 2290-2301.

https://doi.org/10.1890/07-1206.1

Zuur, A.F., Ieno, E.N., Walker, N.J., Saveliev, A.A. \& Smith, G.M. (2009). Mixed Effects Models and Extensions in Ecology with R. Springer Science \& Business Media, New York. 
Table 1. Linear Mixed Model (LMMs) results for all biological indices considered in the BACI analysis. (a) National level n. $=5,988$ samples; (b) Autumn dataset; (c) Spring dataset. Basin level results available in S9. *** $<0.001 ; * * p<0.01 ; * p<0.05$

\begin{tabular}{lrrrrl}
\hline a) National level (all samples) & & & & & \\
\hline WHPT Total & & & & & \\
& Sum Sq & DenDF & F value & $p$-value & \\
BA & 0.55 & 51.0 & 1.60 & 0.2114 & \\
CI & 2.11 & 262.2 & 6.12 & 0.0140 & $*$ \\
BA:CI & 35.08 & 4809.6 & 101.71 & $<2 \mathrm{e}-16$ & $* * *$ \\
\hline WHPT-ASPT & & & & & \\
& Sum Sq & DenDF & F value & $p$-value & \\
BA & 0.95 & 218.4 & 6.03 & 0.0148 & $*$ \\
CI & 2.38 & 259.5 & 15.17 & 0.0001 & $* * *$ \\
BA:CI & 0.02 & 5391.1 & 0.14 & 0.7057 & \\
\hline
\end{tabular}

LIFE Index

BA

CI

BA:CI

Sum Sq DenDF F value p-value

$\begin{array}{llll}0.62 & 211.0 & 2.66 & 0.1045\end{array}$

$\begin{array}{llll}9.69 & 261.0 & 41.45 & 5.77 \mathrm{e}-10\end{array}$

PSI Index

$\begin{array}{llll}0.00 & 5388.1 & 0.00 & 0.9631\end{array}$

\begin{tabular}{lrrrrl} 
PSI Index & Sum Sq & DenDF & F value & $p$-value & \\
& 0.84 & 116.3 & 4.12 & 0.0447 & $*$ \\
BA & 14.78 & 260.0 & 72.66 & $1.27 \mathrm{e}-15$ & $* * *$ \\
CI & 1.77 & 5170.3 & 8.68 & 0.0032 & $* *$ \\
BA:CI & & & & & \\
\hline
\end{tabular}

Func. Richness

BA

CI

Sum $\mathrm{Sq}$ DenDF $\mathrm{F}$ value $p$-value

$\begin{array}{llll}8.82 & 57.5 & 13.12 & 0.0006\end{array}$

BA:CI

$\begin{array}{llll}0.04 & 267.1 & 0.07 & 0.7984\end{array}$

Func. Redundancy

$\begin{array}{llll}44.90 & 4912.0 & 66.80 & 3.79 \mathrm{e}-16\end{array}$

BA

CI

Sum $\mathrm{Sq}$ DenDF F value p-value

$\begin{array}{llll}0.98 & 37.6 & 1.40 & 0.2442\end{array}$

$\mathrm{BA}: \mathrm{CI}$

$\begin{array}{llll}6.36 & 285.9 & 9.06 & 0.0028\end{array}$

$\begin{array}{llll}26.26 & 4593.9 & 37.41 & 1.04 \mathrm{e}-09\end{array}$

\begin{tabular}{lrrrrr}
\hline b) Autumn dataset & & & & & \\
\hline WHPT Total & & & & & \\
& Sum Sq & DenDF & F value & $p$-value & \\
BA & 1.21 & 33.3 & 3.71 & 0.0626 & \\
CI & 2.32 & 271.3 & 7.12 & 0.0081 & $* *$ \\
BA:CI & 13.88 & 2012.3 & 42.57 & $8.61 \mathrm{e}-11$ & $* * *$ \\
\hline WHPT-ASPT & & & & & \\
& Sum Sq & DenDF & F value & $p$-value &
\end{tabular}




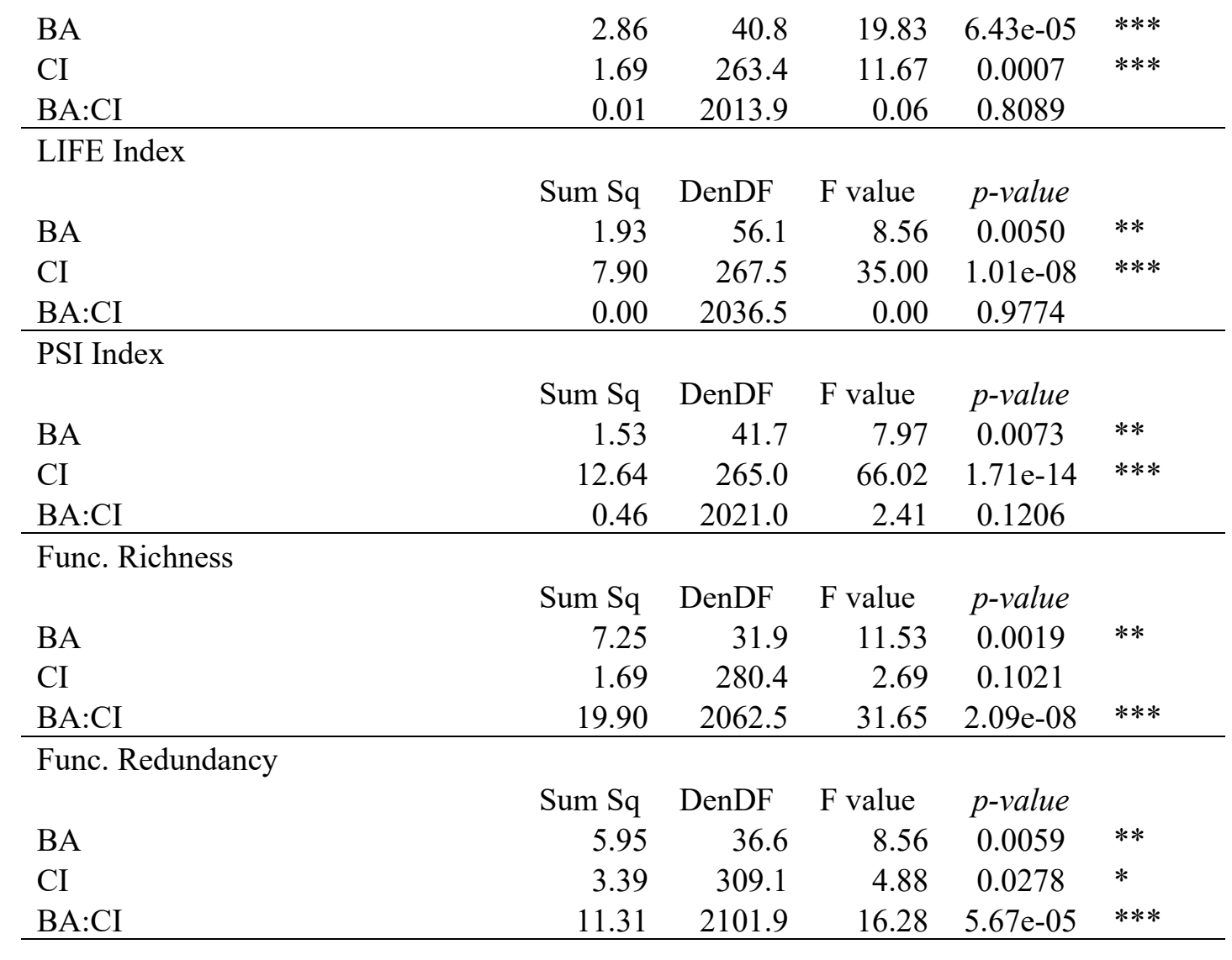

\begin{tabular}{lrrrrr}
\hline c) Spring dataset & & & & & \\
\hline WHPT Total & & & & & \\
& Sum Sq & DenDF & F value & $p$-value & \\
BA & 0.01 & 55.0 & 0.02 & 0.8821 & \\
CI & 2.28 & 269.2 & 7.09 & 0.0082 & $* *$ \\
BA:CI & 8.14 & 2017.7 & 25.36 & $5.18 \mathrm{e}-07$ & $* * *$ \\
\hline WHPT-ASPT & & & & & \\
& Sum Sq & DenDF & F value & $p$-value & \\
BA & 0.45 & 112.3 & 3.39 & 0.0684 & \\
CI & 2.32 & 263.4 & 17.40 & $4.12 \mathrm{e}-05$ & $* * *$ \\
BA:CI & 0.01 & 2078.4 & 0.05 & 0.8166 & \\
\hline
\end{tabular}

LIFE Index

BA

Sum $\mathrm{Sq}$ DenDF F value $p$-value

CI $\begin{array}{llll}0.40 & 103.0 & 1.99 & 0.1611\end{array}$

$\begin{array}{llrrr}\text { BA:CI } & 0.12 & 2081.0 & 0.58 & 0.4447\end{array}$

PSI Index

BA

Sum $\mathrm{Sq}$ DenDF F value p-value

CI

$\begin{array}{llll}0.21 & 89.6 & 1.16 & 0.2851\end{array}$

BA:CI

$\begin{array}{llll}12.88 & 263.5 & 72.20 & 1.45 \mathrm{e}-15\end{array}$

Func. Richness

$\begin{array}{llll}0.19 & 2067.0 & 1.05 & 0.3065\end{array}$

\begin{tabular}{lrrrrl} 
& Sum Sq & DenDF & F value & $p$-value & \\
BA & 3.63 & 47.4 & 5.46 & 0.0237 & $*$ \\
CI & 0.09 & 276.3 & 0.14 & 0.7082 & \\
BA:CI & 23.04 & 2041.4 & 34.70 & $4.49 \mathrm{e}-09$ & $* * *$ \\
\hline
\end{tabular}


Func. Redundancy

\begin{tabular}{rrrrl} 
Sum Sq & DenDF & F value & $p$-value & \\
2.19 & 37.1 & 3.31 & 0.0771 & \\
6.16 & 295.8 & 9.31 & 0.0025 & $* *$ \\
2.54 & 1797.8 & 3.84 & 0.0502 &. \\
\hline
\end{tabular}

799

800

801

802

803

804

805

806

807

808

809

810

811

812

813

814

815

816

817

818

819

820

821

822

823

824

825

826

827

828

829

830 


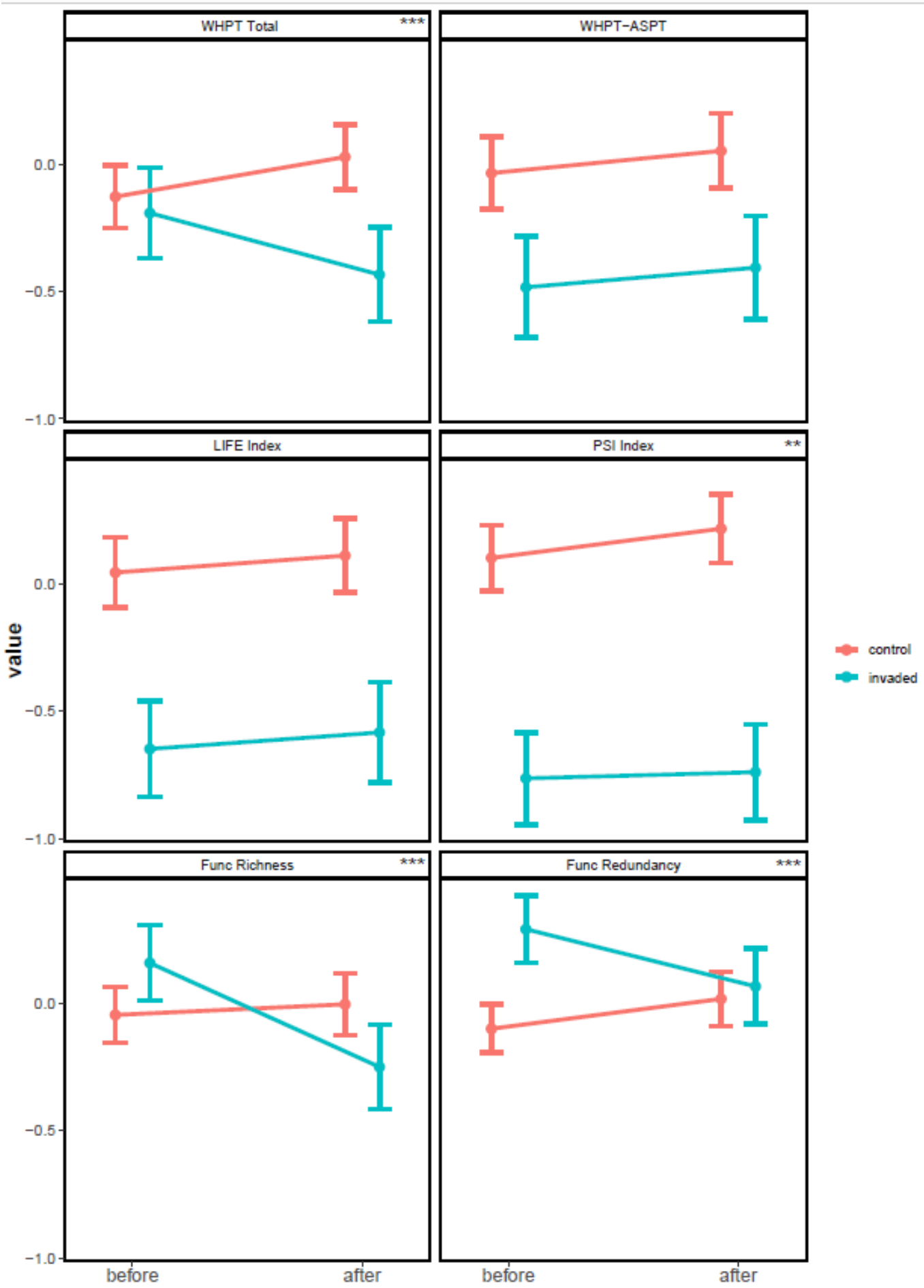

Figure 1. Responses of the 6 biological indices considered at the national scale (England). Control

835 (red) and invaded samples (blue) are displayed before and after invasion of D. haemobaphes. Mean

836 and $95 \%$ coefficient intervals are shown. Metrics standardised to $z$-scores on the y-axis. ${ }^{* * *} \mathrm{p}<0.001$;

$837 * * \mathrm{p}<0.01 ; * \mathrm{p}<0.05$ 

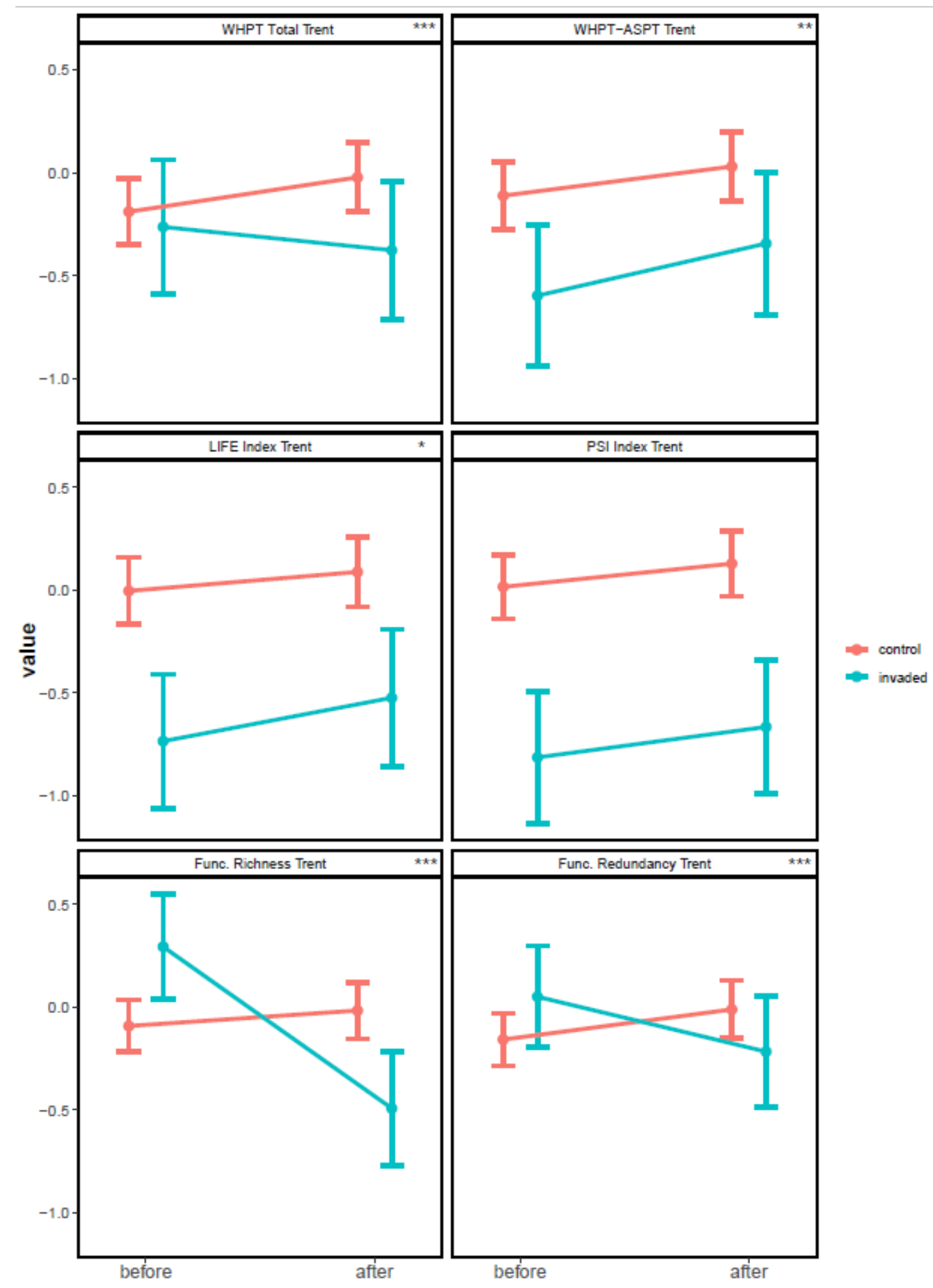

843 Figure 2. Responses of the 6 biological indexes considered at the basin level (Trent river basin).

844 Control (red) and invaded (blue) samples are displayed before and after invasion of D. haemobaphes.

845 Mean and 95\% coefficient intervals are shown. Metrics standardised to z-scores on the y-axis. ***p < $0.001 ; * * \mathrm{p}<0.01 ; * \mathrm{p}<0.05$ 


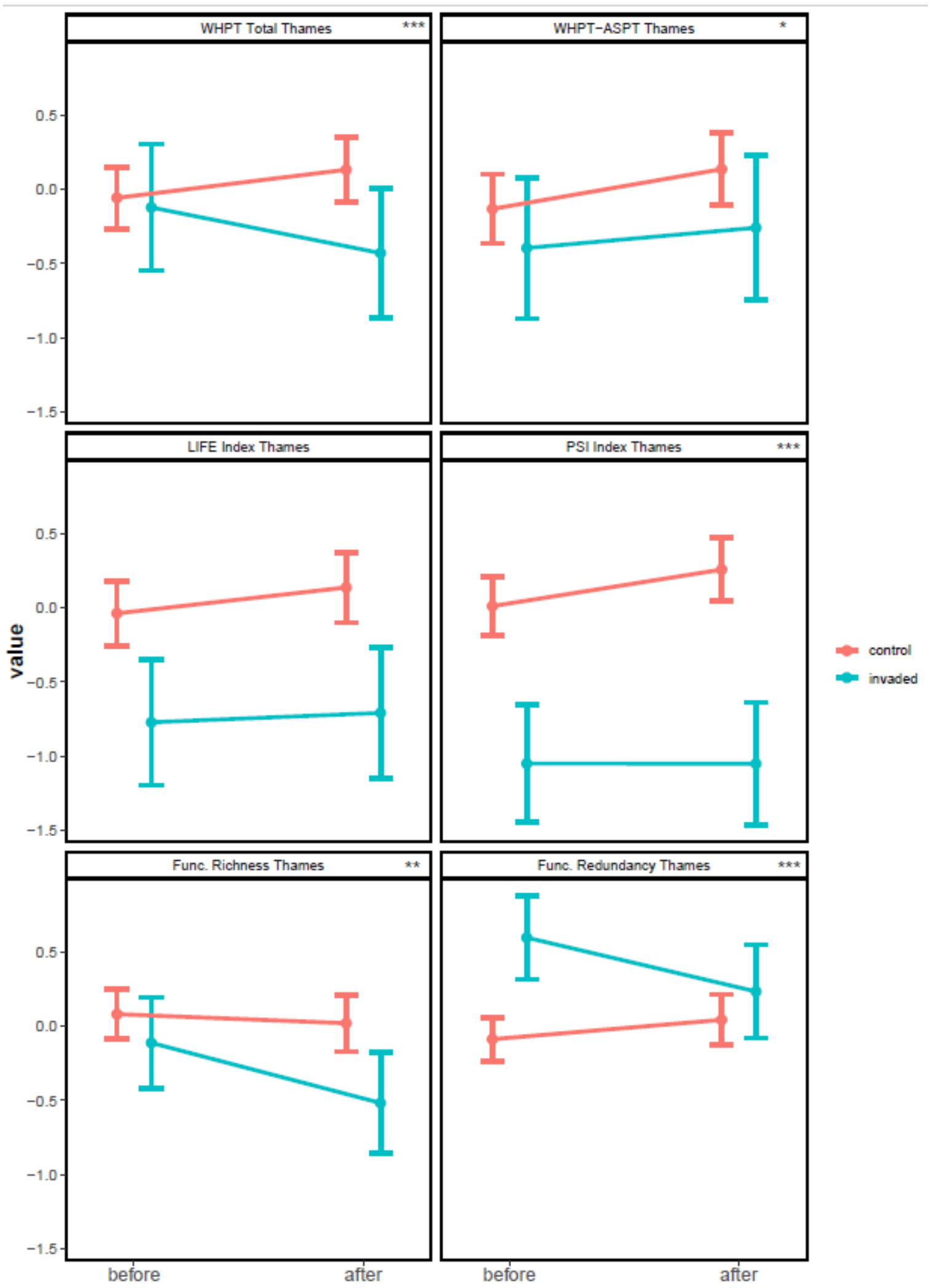

848 Figure 3. Responses of the 6 biological indexes considered at the basin level (Thames river basin).

849 Control (red) and invaded (blue) samples are displayed before and after invasion of D. haemobaphes.

850 Mean and $95 \%$ coefficient intervals are shown. Metrics standardised to z-scores on the y-axis. ${ }^{* * *} \mathrm{p}<$

$851 \quad 0.001 ; * * \mathrm{p}<0.01 ; * \mathrm{p}<0.05$ 


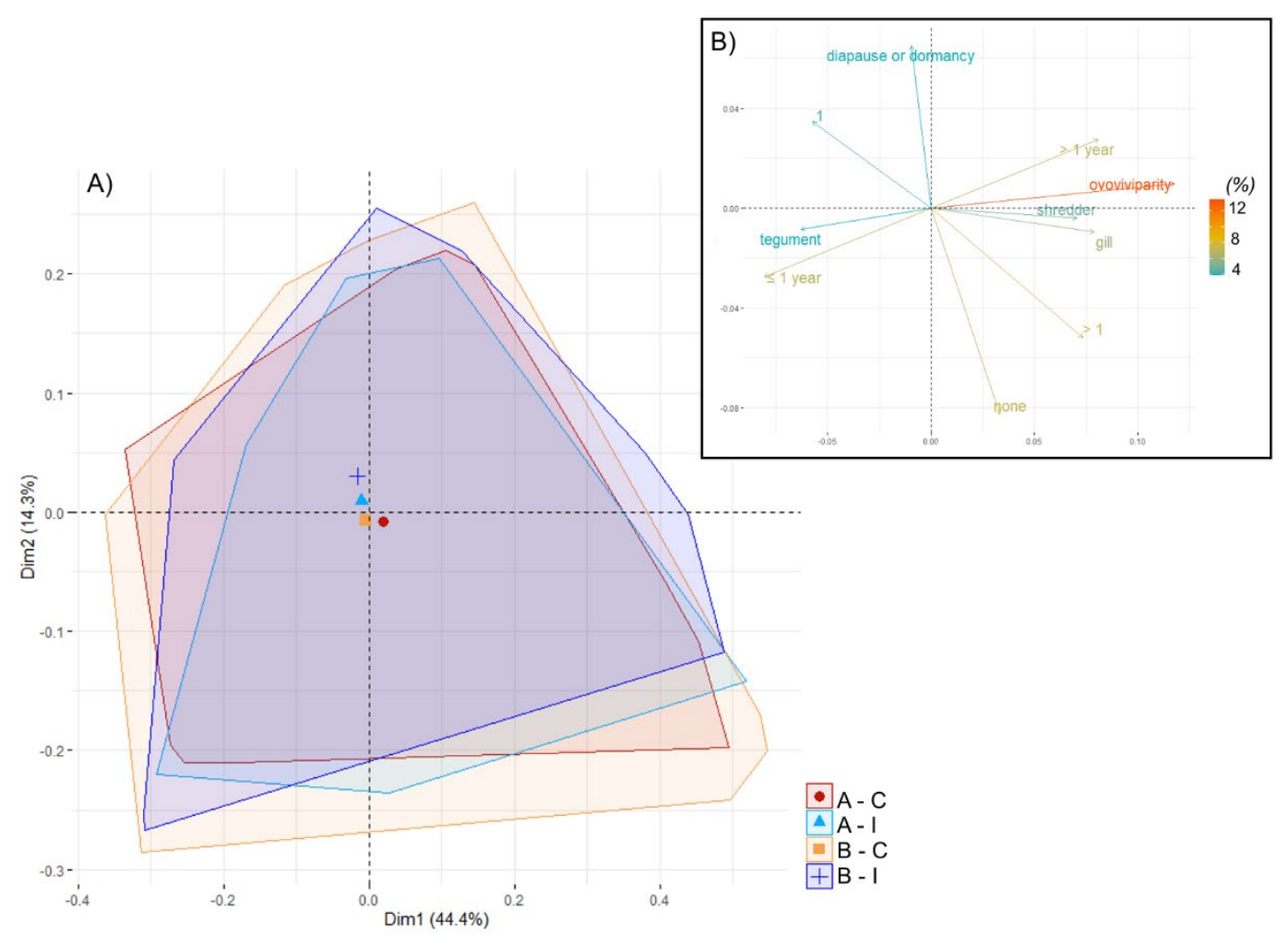

Figure 4. Fuzzy Principle Components Analysis (FPCA) ordination showing a) the centroids for

854 macroinvertebrate community functional trait composition at the national level (England); b) the main

855 biological traits driving community functional composition. First 2 axes account for $58.7 \%$ of the

856 statistical variation. Each BACI level is enclosed in a convex hull corresponding to all samples in the

857 group. $(\%)=$ percentage contribution of each modality to the trait-based ordination. After Control $=$

858 red circle; After Invaded = light blue triangle; Before Control = orange square; Before Invaded = dark

859 blue cross. For FPCA plots at basin level please see S10- S11. 


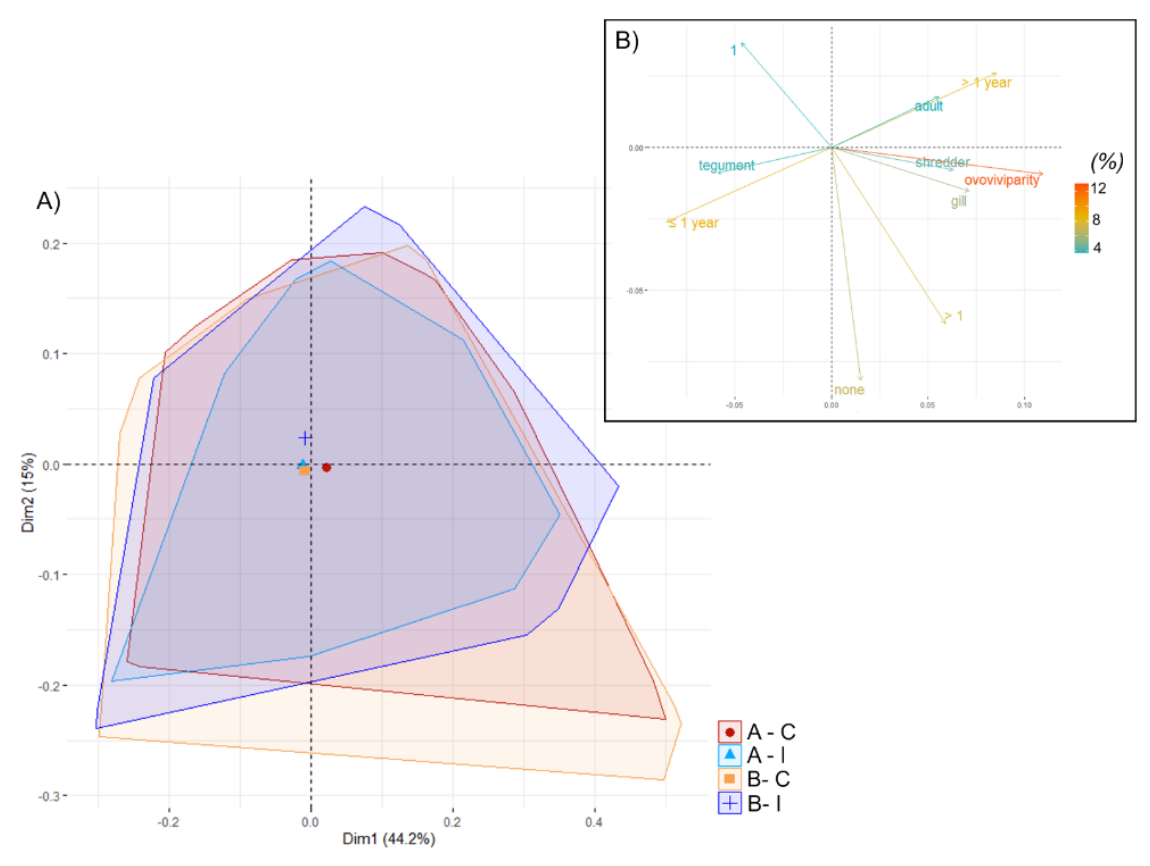

862 Figure 5. Fuzzy Principle Components Analysis (FPCA) ordination showing a) the centroids of

863 functional community composition for the spring dataset (England); b) the main biological traits in

864 driving the functional composition ordination. Each BACI level is enclosed in a convex hull

865 corresponding to all replicate samples. $(\%)=$ percentage contribution of each modality to the trait-

866 based ordination. After Control = red circle; After Invaded = light blue triangle; Before Control =

867 orange square; Before Invaded $=$ dark blue cross. 
887 S1. Environmental Agency of England macroinvertebrate sampling site dataset used in this study $(n=259)$. Information for water bodies, river basin and treatment (control or invaded) is also provided.

S2. Map of study sites employed with main catchment boundaries (Trent and Thames) delineated. Schmidt-Kloiber and Hering, 2015).

S4. Spearman rank correlations among all the biological indices analysed.

$* * * \mathrm{p}<0.001 ; * * \mathrm{p}<0.01 ; * \mathrm{p}<0.05$

S5. Responses of the 6 biological indexes analysed for the Autumn dataset (England). y-axis. ${ }^{* * *} \mathrm{p}<0.001 ;{ }^{* *} \mathrm{p}<0.01 ;{ }^{*} \mathrm{p}<0.05$

S6. Responses of the 6 biological indexes analysed for the Spring dataset (England). haemobaphes. Mean and 95\% coefficient intervals are shown. Metrics standardised to z-scores on the y-axis. ${ }^{* *}$ p $<0.001 ; * * p<0.01 ;{ }^{*} p<0.05$

S7. Fuzzy Principle Components Analysis (FPCA) ordination showing a) the centroids of functional community composition for the autumn dataset (England); b) the main biological traits in driving the functional composition ordination. Each BACI level is enclosed in a convex hull corresponding to all replicate samples. $(\%)=$ percentage contribution of each modality to the trait-based ordination. After

913 Control = red circle; After Invaded = light blue triangle; Before Control = orange square; Before Invaded $=$ dark blue cross.

S8. Results of the 1,000 simulations to assess the consistency of the outputs for function composition analysis at all levels (national, basin, season). Slope and distance between the before and after of the invaded and control samples have been assessed. Mean and 95\% coefficient intervals are shown. Distance $=\mathrm{n}$. of time the distance between centroids (before vs after) is greater for invaded samples $(1=100 \%)$. 
S9. Linear Mixed Model (LMMs) results for all biological indices considered in the BACI analysis at

923 the basin (Trent and Thames) level. ***p $<0.001 ; * * \mathrm{p}<0.01 ;{ }^{*} \mathrm{p}<0.05$

925 S10. Fuzzy Principle Components Analysis (FPCA) ordination showing a) the centroids for

926 macroinvertebrate community functional trait composition for the River Trent basin; b) the main

927 biological traits in driving the functional composition ordination. Each BACI level is enclosed in a

928 convex hull corresponding to all replicate samples. $(\%)=$ percentage contribution of each modality to

929 the trait-based ordination. After Control = red circle; After Invaded = light blue triangle; Before

930 Control $=$ orange square; Before Invaded $=$ dark blue cross.

931

932 S11. Fuzzy Principle Components Analysis (FPCA) ordination showing a) the centroids of functional

933 macroinvertebrate community composition for the River Thames basin dataset; $b$ ) the main biological

934 traits driving community functional composition ordination. Each BACI level is enclosed in a convex

935 hull corresponding to all replicate samples in the group. (\%) = percentage contribution of each

936 modality to the trait-based ordination. After Control = red circle; After Invaded = light blue triangle;

937 Before Control = orange square; Before Invaded = dark blue cross. 
Guareschi et al._JAPPL_APPENDIX__ 2

Appendix S1_sites list__ 4

Appendix S2_map 10

Appendix S3 11

Appendix S4 12

Appendix S5 13

Appendix S6 14

Appendix S7 15

Appendix S8 16

Appendix S9 17

Appendix S10 19

Appendix S11 20 
887 S1. Environmental Agency of England macroinvertebrate sampling site dataset used in this study $(n=259)$. Information for water bodies, river basin and treatment (control or invaded) is also provided.

S2. Map of study sites employed with main catchment boundaries (Trent and Thames) delineated. Schmidt-Kloiber and Hering, 2015).

S4. Spearman rank correlations among all the biological indices analysed.

$* * * \mathrm{p}<0.001 ; * * \mathrm{p}<0.01 ; * \mathrm{p}<0.05$

S5. Responses of the 6 biological indexes analysed for the Autumn dataset (England). y-axis. ${ }^{* * *} \mathrm{p}<0.001 ;{ }^{* *} \mathrm{p}<0.01 ;{ }^{*} \mathrm{p}<0.05$

S6. Responses of the 6 biological indexes analysed for the Spring dataset (England). haemobaphes. Mean and 95\% coefficient intervals are shown. Metrics standardised to z-scores on the y-axis. ${ }^{* *}$ p $<0.001 ; * * p<0.01 ;{ }^{*} p<0.05$

S7. Fuzzy Principle Components Analysis (FPCA) ordination showing a) the centroids of functional community composition for the autumn dataset (England); b) the main biological traits in driving the functional composition ordination. Each BACI level is enclosed in a convex hull corresponding to all replicate samples. $(\%)=$ percentage contribution of each modality to the trait-based ordination. After

913 Control = red circle; After Invaded = light blue triangle; Before Control = orange square; Before Invaded $=$ dark blue cross.

S8. Results of the 1,000 simulations to assess the consistency of the outputs for function composition analysis at all levels (national, basin, season). Slope and distance between the before and after of the invaded and control samples have been assessed. Mean and 95\% coefficient intervals are shown. Distance $=\mathrm{n}$. of time the distance between centroids (before vs after) is greater for invaded samples $(1=100 \%)$. 
S9. Linear Mixed Model (LMMs) results for all biological indices considered in the BACI analysis at

923 the basin (Trent and Thames) level. ***p $<0.001 ; * * \mathrm{p}<0.01 ;{ }^{*} \mathrm{p}<0.05$

925 S10. Fuzzy Principle Components Analysis (FPCA) ordination showing a) the centroids for

926 macroinvertebrate community functional trait composition for the River Trent basin; b) the main

927 biological traits in driving the functional composition ordination. Each BACI level is enclosed in a

928 convex hull corresponding to all replicate samples. $(\%)=$ percentage contribution of each modality to

929 the trait-based ordination. After Control = red circle; After Invaded = light blue triangle; Before

930 Control $=$ orange square; Before Invaded $=$ dark blue cross.

931

932 S11. Fuzzy Principle Components Analysis (FPCA) ordination showing a) the centroids of functional

933 macroinvertebrate community composition for the River Thames basin dataset; $b$ ) the main biological

934 traits driving community functional composition ordination. Each BACI level is enclosed in a convex

935 hull corresponding to all replicate samples in the group. (\%) = percentage contribution of each

936 modality to the trait-based ordination. After Control = red circle; After Invaded = light blue triangle;

937 Before Control = orange square; Before Invaded = dark blue cross. 



\begin{tabular}{|c|c|c|c|}
\hline 35402 & WEY (NORTH) & Thames & control \\
\hline 82078 & WEY (SOUTH) & Thames & control \\
\hline 35791 & WHITEWATER (LODDON) & Thames & control \\
\hline 35792 & WHITEWATER (LODDON) & Thames & control \\
\hline 96883 & AMPNEY BROOK & Thames & control \\
\hline 36186 & COLN & Thames & control \\
\hline 36204 & COLN & Thames & control \\
\hline 36133 & EVENLODE & Thames & control \\
\hline 35491 & KENNET & Thames & control \\
\hline 36079 & KENNET & Thames & control \\
\hline 36072 & LAMBOURN & Thames & control \\
\hline 36073 & LAMBOURN & Thames & control \\
\hline 35007 & LEACH & Thames & control \\
\hline 35965 & OG & Thames & control \\
\hline 35443 & PANG & Thames & control \\
\hline 35939 & SOR BROOK & Thames & control \\
\hline 35911 & THAME & Thames & control \\
\hline 35799 & WINDRUSH & Thames & control \\
\hline 35528 & WYE (THAMES & Thames & control \\
\hline 35782 & WYE (THAMES & Thames & control \\
\hline 49859 & ALFRETON BROOK & Trent & control \\
\hline 48583 & AMBER & Trent & control \\
\hline 52265 & AMBER & Trent & control \\
\hline 53167 & AMBER & Trent & control \\
\hline 53845 & AMBER & Trent & control \\
\hline 53846 & AMBER & Trent & control \\
\hline 97161 & ASHOP & Trent & control \\
\hline 47616 & ASHWELL BROOK & Trent & control \\
\hline 47156 & BAGTHORPE BROOK & Trent & control \\
\hline 50336 & BAILEY BROOK & Trent & control \\
\hline 50817 & BAKER LANE BROOK & Trent & control \\
\hline 52380 & BECK DYKE & Trent & control \\
\hline 47672 & BENTLEY BROOK & Trent & control \\
\hline 50623 & BEVERCOTES BECK & Trent & control \\
\hline 51073 & BLACK BROOK & Trent & control \\
\hline 52189 & BLACK BROOK & Trent & control \\
\hline 47661 & BOTTLE BROOK & Trent & control \\
\hline 50583 & BOTTLE BROOK & Trent & control \\
\hline 52534 & BOTTLE BROOK & Trent & control \\
\hline 53857 & BRADFORD BROOK & Trent & control \\
\hline 50020 & BRADGATE BROOK & Trent & control \\
\hline 47612 & BROADBRIDGE DYKE & Trent & control \\
\hline 52704 & BROADBRIDGE DYKE & Trent & control \\
\hline 48599 & BROUGHTON ASTLEY BROOK & Trent & control \\
\hline 51466 & COCKER BECK & Trent & control \\
\hline 46924 & DERWENT (LT) & Trent & control \\
\hline 47057 & DERWENT (LT) & Trent & control \\
\hline 47138 & DERWENT (LT) & Trent & control \\
\hline 50454 & DERWENT (LT) & Trent & control \\
\hline 51342 & DERWENT (LT) & Trent & control \\
\hline 51495 & DERWENT (LT) & Trent & control \\
\hline 53543 & DERWENT (LT) & Trent & control \\
\hline
\end{tabular}




\begin{tabular}{|c|c|c|c|}
\hline 53618 & DERWENT (LT) & Trent & control \\
\hline 53873 & DERWENT (LT) & Trent & control \\
\hline 47206 & DEVON & Trent & control \\
\hline 51330 & DEVON & Trent & control \\
\hline 51838 & DOVER BECK & Trent & control \\
\hline 52988 & DOVER BECK & Trent & control \\
\hline 153886 & DOVER BECK & Trent & control \\
\hline 49026 & EAU & Trent & control \\
\hline 50016 & EAU & Trent & control \\
\hline 49700 & ECCLESBOURNE (River ECCLESBOURNE) & Trent & control \\
\hline 52718 & ECCLESBOURNE (River ECCLESBOURNE) & Trent & control \\
\hline 48442 & EYE & Trent & control \\
\hline 49040 & EYE & Trent & control \\
\hline 52587 & EYE & Trent & control \\
\hline 52768 & FLEET & Trent & control \\
\hline 154963 & GILT BROOK & Trent & control \\
\hline 154964 & GILT BROOK & Trent & control \\
\hline 154965 & GILT BROOK & Trent & control \\
\hline 47538 & GRACE DIEU BROOK & Trent & control \\
\hline 52301 & GRACE DIEU BROOK & Trent & control \\
\hline 48568 & GREET & Trent & control \\
\hline 50964 & GREET & Trent & control \\
\hline 52726 & HARBY BROOK & Trent & control \\
\hline 51253 & HATFIELD WASTE DRAIN & Trent & control \\
\hline 51064 & HEATH END BROOK & Trent & control \\
\hline 53594 & IDLE & Trent & control \\
\hline 78923 & JAGGERS CLOUGH & Trent & control \\
\hline 47617 & LANGHAM BROOK & Trent & control \\
\hline 53858 & LATHKILL & Trent & control \\
\hline 50048 & LEEN & Trent & control \\
\hline 51280 & LEEN & Trent & control \\
\hline 53426 & LEEN & Trent & control \\
\hline 52417 & LUBBESTHORPE BK (EX BIAM) & Trent & control \\
\hline 50963 & MACKWORTH BROOK & Trent & control \\
\hline 51044 & MARKEATON BROOK & Trent & control \\
\hline 47100 & MAUN & Trent & control \\
\hline 51324 & MAUN & Trent & control \\
\hline 50765 & MEDEN & Trent & control \\
\hline 51331 & MIDDLE BECK & Trent & control \\
\hline 47592 & NEW BROOK & Trent & control \\
\hline 51204 & NOE & Trent & control \\
\hline 47526 & NORMANTON / THURLASTON BK & Trent & control \\
\hline 52332 & NORMANTON / THURLASTON BK & Trent & control \\
\hline 53424 & OLDCOTES DYKE & Trent & control \\
\hline 53214 & OUSE DYKE & Trent & control \\
\hline 52322 & PICKWELL BROOK EAST & Trent & control \\
\hline 48605 & PICKWELL BROOK WEST & Trent & control \\
\hline 50094 & POULTER & Trent & control \\
\hline 51896 & POULTER & Trent & control \\
\hline 52480 & POULTER & Trent & control \\
\hline 52504 & POULTER & Trent & control \\
\hline 153578 & RADBOURNE BK & Trent & control \\
\hline
\end{tabular}




\begin{tabular}{|c|c|c|c|}
\hline 49170 & RAINWORTH WATER & Trent & control \\
\hline 49363 & RAINWORTH WATER & Trent & control \\
\hline 153552 & RAMSLEY BROOK & Trent & control \\
\hline 53705 & RANSKILL BROOK & Trent & control \\
\hline 53835 & ROTHLEY BROOK & Trent & control \\
\hline 48913 & RYTON & Trent & control \\
\hline 49366 & RYTON & Trent & control \\
\hline 51015 & SENCE (SOAR) & Trent & control \\
\hline 52426 & SENCE (SOAR) & Trent & control \\
\hline 52727 & SHILTON BROOK & Trent & control \\
\hline 52772 & SMITE & Trent & control \\
\hline 52495 & SOAR & Trent & control \\
\hline 47122 & SOMERBY BROOK & Trent & control \\
\hline 51065 & STAUNTON HAROLD BROOK & Trent & control \\
\hline 48272 & SYSTON BROOK & Trent & control \\
\hline 52501 & THE BECK & Trent & control \\
\hline 51118 & THURLASTON BROOK & Trent & control \\
\hline 53757 & TORNE & Trent & control \\
\hline 53150 & WALTON BROOK & Trent & control \\
\hline 47147 & WHETSTONE BROOK & Trent & control \\
\hline 47615 & WHISSENDINE BROOK & Trent & control \\
\hline 50146 & WOOD BROOK & Trent & control \\
\hline 50349 & WYE (LT) & Trent & control \\
\hline 53811 & WYE (LT) & Trent & control \\
\hline 53819 & WYE (LT) & Trent & control \\
\hline 56208 & KINGS DYKE & Ouse & impact \\
\hline 56235 & OUSE (KYM) & Ouse & impact \\
\hline 56310 & OUSE (OUZEL) & Ouse & impact \\
\hline 56407 & OUSE (OUZEL) & Ouse & impact \\
\hline 56143 & OUSE (ST IVES) & Ouse & impact \\
\hline 56164 & OUSE (ST IVES) & Ouse & impact \\
\hline 56439 & OUZEL & Ouse & impact \\
\hline 56453 & TOVE & Ouse & impact \\
\hline 55583 & GWASH & Welland & impact \\
\hline 55669 & NENE & Nene & impact \\
\hline 55673 & NENE & Nene & impact \\
\hline 55676 & NENE & Nene & impact \\
\hline 55678 & NENE & Nene & impact \\
\hline 55694 & NENE & Nene & impact \\
\hline 55697 & NENE & Nene & impact \\
\hline 55698 & NENE & Nene & impact \\
\hline 55722 & PITSFORD ARM/FAXTON BROOK & Nene & impact \\
\hline 75913 & AVON (LS - SOWE TO BIDFORD) & Severn & impact \\
\hline 48445 & AVON (LS - ABOVE SOWE) & Severn & impact \\
\hline 53305 & AVON (LS - ABOVE SOWE) & Severn & impact \\
\hline 154944 & AVON (LS - ABOVE SOWE) & Severn & impact \\
\hline 158736 & AVON (LS - ABOVE SOWE) & Severn & impact \\
\hline 53026 & CARLTON BROOK & Trent & impact \\
\hline 47062 & LEAM & Severn & impact \\
\hline 49704 & LEAM & Severn & impact \\
\hline 51122 & LEAM & Severn & impact \\
\hline 46926 & River Trent & Trent & impact \\
\hline
\end{tabular}




\begin{tabular}{|c|c|c|c|}
\hline 47273 & River Trent & Trent & impact \\
\hline 51394 & River Trent & Trent & impact \\
\hline 51508 & River Trent & Trent & impact \\
\hline 48476 & SOW & Trent & impact \\
\hline 50369 & SOW & Trent & impact \\
\hline 52917 & TAME (UT) & Trent & impact \\
\hline 48459 & EREWASH & Trent & impact \\
\hline 50294 & IDLE & Trent & impact \\
\hline 47275 & SOAR & Trent & impact \\
\hline 48468 & SOAR & Trent & impact \\
\hline 48888 & SOAR & Trent & impact \\
\hline 49307 & SOAR & Trent & impact \\
\hline 53754 & SOAR & Trent & impact \\
\hline 46894 & Trent & Trent & impact \\
\hline 47046 & Trent & Trent & impact \\
\hline 47063 & Trent & Trent & impact \\
\hline 48580 & Trent & Trent & impact \\
\hline 49039 & Trent & Trent & impact \\
\hline 50916 & Trent & Trent & impact \\
\hline 51467 & Trent & Trent & impact \\
\hline 47608 & WOOD BROOK & Trent & impact \\
\hline 52341 & WOOD BROOK & Trent & impact \\
\hline 48328 & AVON (LS - BELOW BIDFORD) & Severn & impact \\
\hline 51827 & AVON (LS - BELOW BIDFORD) & Severn & impact \\
\hline 53747 & AVON (LS - BELOW BIDFORD) & Severn & impact \\
\hline 51524 & MEESE & Severn & impact \\
\hline 51368 & SALWARPE & Severn & impact \\
\hline 52933 & SALWARPE & Severn & impact \\
\hline 51208 & SEVERN & Severn & impact \\
\hline 48200 & SEVERN (LS) & Severn & impact \\
\hline 51037 & SEVERN (LS) & Severn & impact \\
\hline 51327 & SEVERN (LS) & Severn & impact \\
\hline 172484 & SEVERN (LS) & Severn & impact \\
\hline 51807 & STOUR (US) & Severn & impact \\
\hline 153543 & STOUR (US) & Severn & impact \\
\hline 67296 & DOUGLAS & Ribble & impact \\
\hline 69695 & DOUGLAS & Ribble & impact \\
\hline 66940 & GOWY & Mersy & impact \\
\hline 68460 & GOWY & Mersy & impact \\
\hline 66935 & WEAVER & Mersy & impact \\
\hline 34013 & COLNE BROOK & Thames & impact \\
\hline 33600 & LEE (NAV.SUB A) & Thames & impact \\
\hline 34158 & LEE (THAMES) & Thames & impact \\
\hline 82437 & ODNEY WEIR STREAM & Thames & impact \\
\hline 35886 & THAMES (SE AREA) & Thames & impact \\
\hline 35889 & THAMES (SE AREA) & Thames & impact \\
\hline 81960 & THAMES (SE AREA) & Thames & impact \\
\hline 98142 & AMES TIDEWAY (THAMES SOUTH-EAST ARH & Thames & impact \\
\hline 36232 & CHERWELL & Thames & impact \\
\hline 36242 & CHERWELL & Thames & impact \\
\hline 36248 & CHERWELL & Thames & impact \\
\hline 36261 & CHERWELL & Thames & impact \\
\hline
\end{tabular}


36262

150066

34459
CHERWELL CHERWELL SEACOURT STREAM
Thames impact

Thames impact

Thames impact 
Table St Macroinvertebrate ō

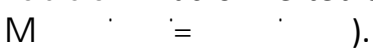

\begin{tabular}{|c|c|c|c|}
\hline Grbluping feature & 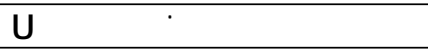 & Grouping feature & 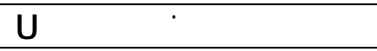 \\
\hline \multirow{7}{*}{ Maximum potential size } & Xi oúŎOr & \multirow{5}{*}{ Respiration method } & Gill \\
\hline & 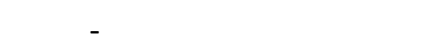 & & Plastron \\
\hline & Ұi đ́́- $1 \mathrm{~cm}$ & & Spiracle \\
\hline & $>1-2 \mathrm{~cm}$ & & Hydrostatic vesicle \\
\hline & $>2-4 \mathrm{~cm}$ & & Tegument \\
\hline & $>4-8 \mathrm{~cm}$ & \multirow{9}{*}{ Food consumed } & Microorganisms \\
\hline & $>8 \mathrm{~cm}$ & & Detritus <1mm \\
\hline \multirow{2}{*}{ Life-cycle duration } & X êsil NJ & & 5Ŝl' ŘLff: yüxj $Y Y$ \\
\hline & $>1$ year & & Living microphytes \\
\hline \multirow{3}{*}{ Voltinism } & $<1$ & & Living macrophtyes \\
\hline & 1 & & 5Ŝl ŘlyA \\
\hline & $>1$ & & Living microinvertebrates \\
\hline \multirow{4}{*}{ Aquatic stages } & Egg & & Living invertebrates \\
\hline & Larva & & Vertebrates \\
\hline & Nymph & & Absorber \\
\hline & Adult & & Deposit feeder \\
\hline \multirow{8}{*}{ Reproduction strategy } & Ovoviviparity & & Shredder \\
\hline & Isolated, free eggs & & Scraper \\
\hline & Isolated, cemented eggs & Feedıng group & Filter-feeder \\
\hline & Clutches, cemented & & Piercer \\
\hline & Clutches, free & & Predator \\
\hline & Clutches, in vegetation & & Parasite \\
\hline & Clutches, terrestrial & & \\
\hline & Asexual & & \\
\hline \multirow{4}{*}{ Dispersal strategy } & Aquatic passive & & \\
\hline & Aquatic active & & \\
\hline & Aerial passive & & \\
\hline & Aerial active & & \\
\hline \multirow{5}{*}{ Resistance form } & Eggs/statoblasts & & \\
\hline & Cocoons & & \\
\hline & Housings against desiccation & & \\
\hline & Diapause / dormancy & & \\
\hline & None & & \\
\hline \multirow{8}{*}{$\begin{array}{l}\text { Locomotion and substrate } \\
\text { relation }\end{array}$} & Flier & & \\
\hline & Surface swimmer & & \\
\hline & Full water swimmer & & \\
\hline & Crawler & & \\
\hline & Burrower & & \\
\hline & Interstitial & & \\
\hline & Temporarily attached & & \\
\hline & Permanently attached & & \\
\hline
\end{tabular}


$\begin{array}{lll}3 & 5 & 7\end{array}$
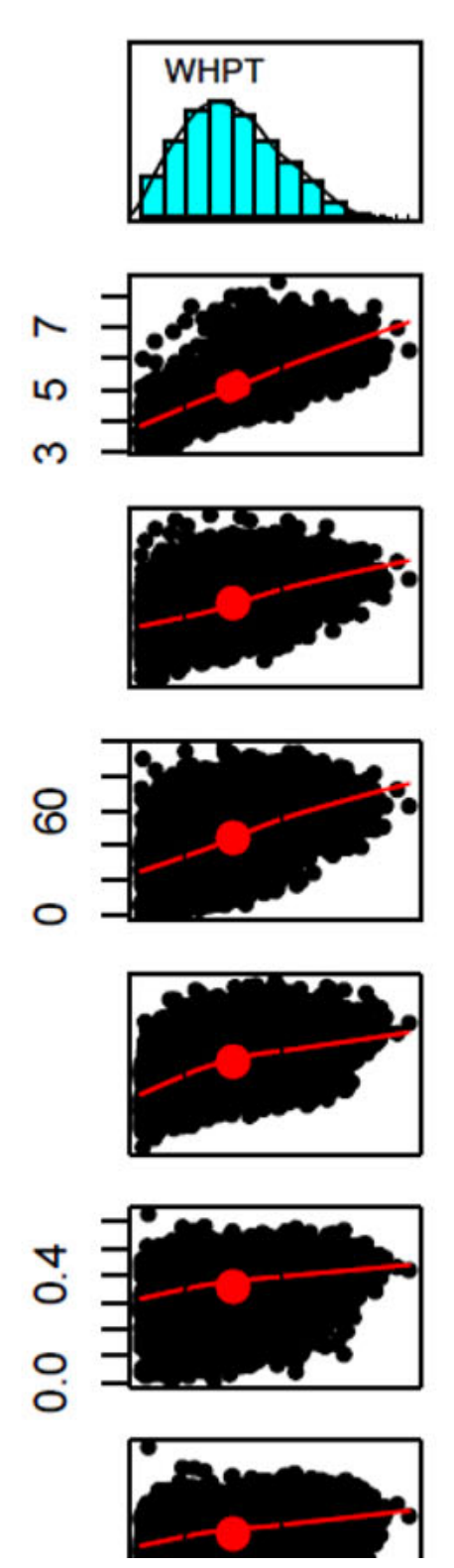

$0 \quad 40 \quad 80$

\begin{tabular}{|c|}
\hline $1 / 1 ـ 1$ \\
\hline $0.53^{* * *}$ \\
\hline
\end{tabular}

$0.37^{* \star *}$
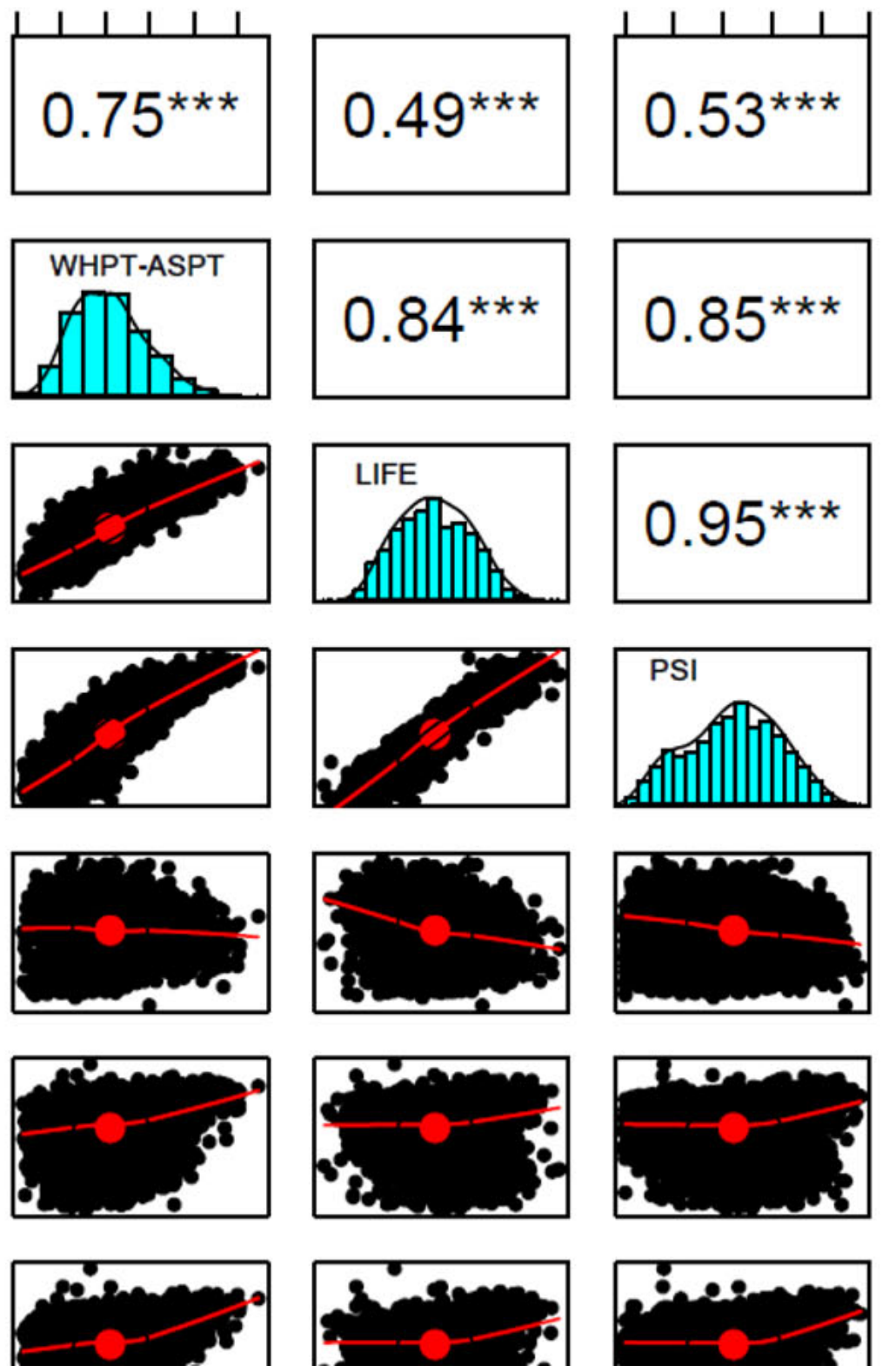

$-0.05^{* * *}$
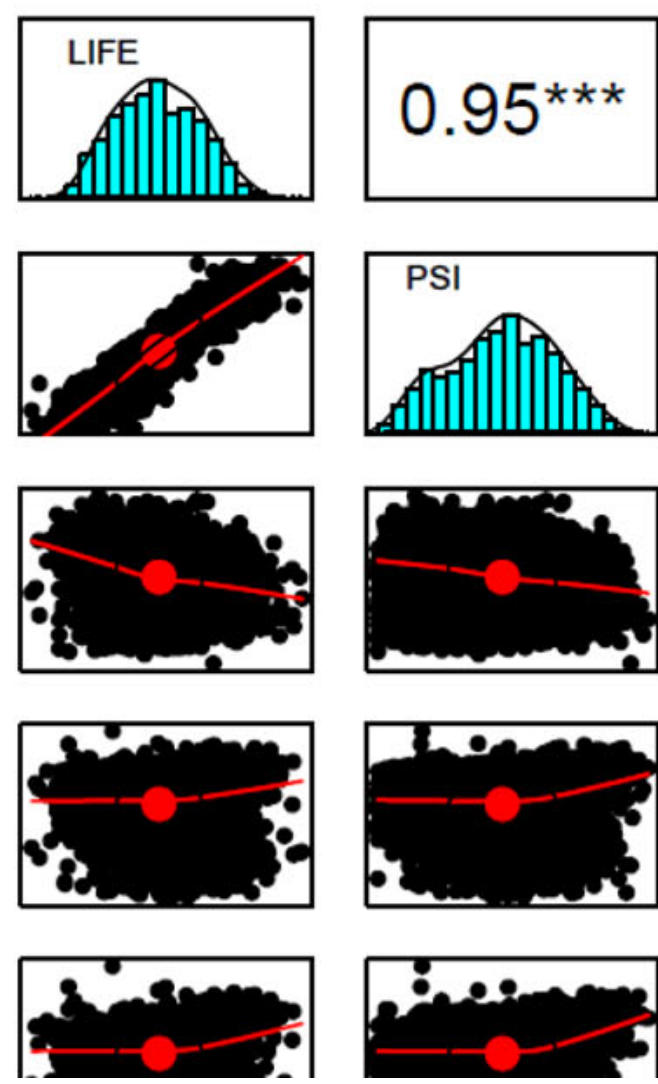

$-0.20^{* * *}$
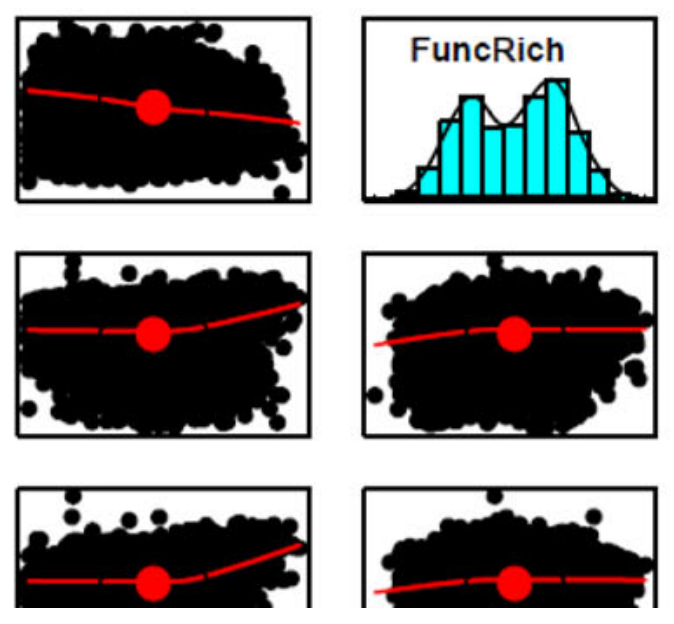

$\begin{array}{lll}0.0 & 0.3 & 0.6\end{array}$

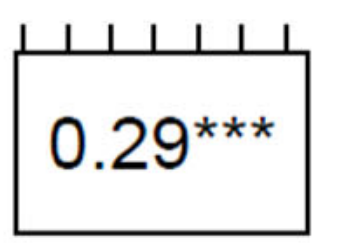

$0.27^{* * *}=\frac{8}{\circ}$
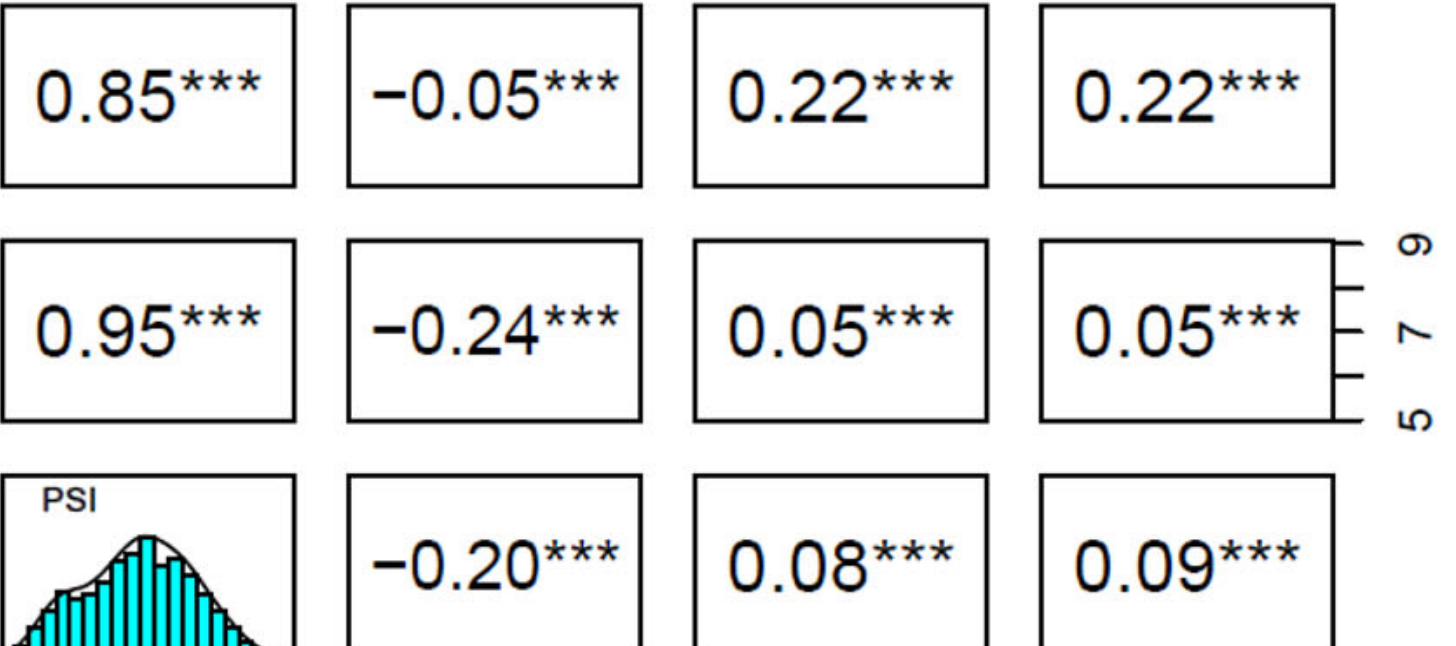

$0.09^{* * *}$

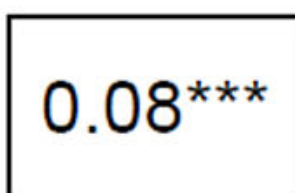

$0.05 * * * \mathrm{E}^{\mathrm{E}}$ 。ั

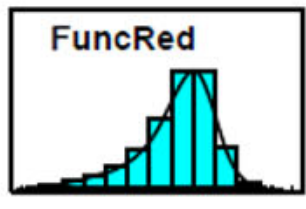

$0.91^{* * *}$
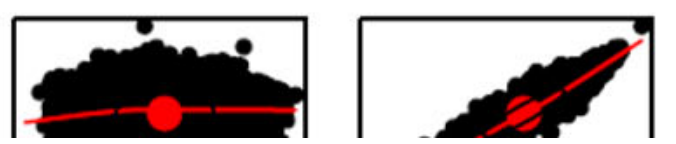

FuncRed_Total AA ${ }^{\circ}$ E 


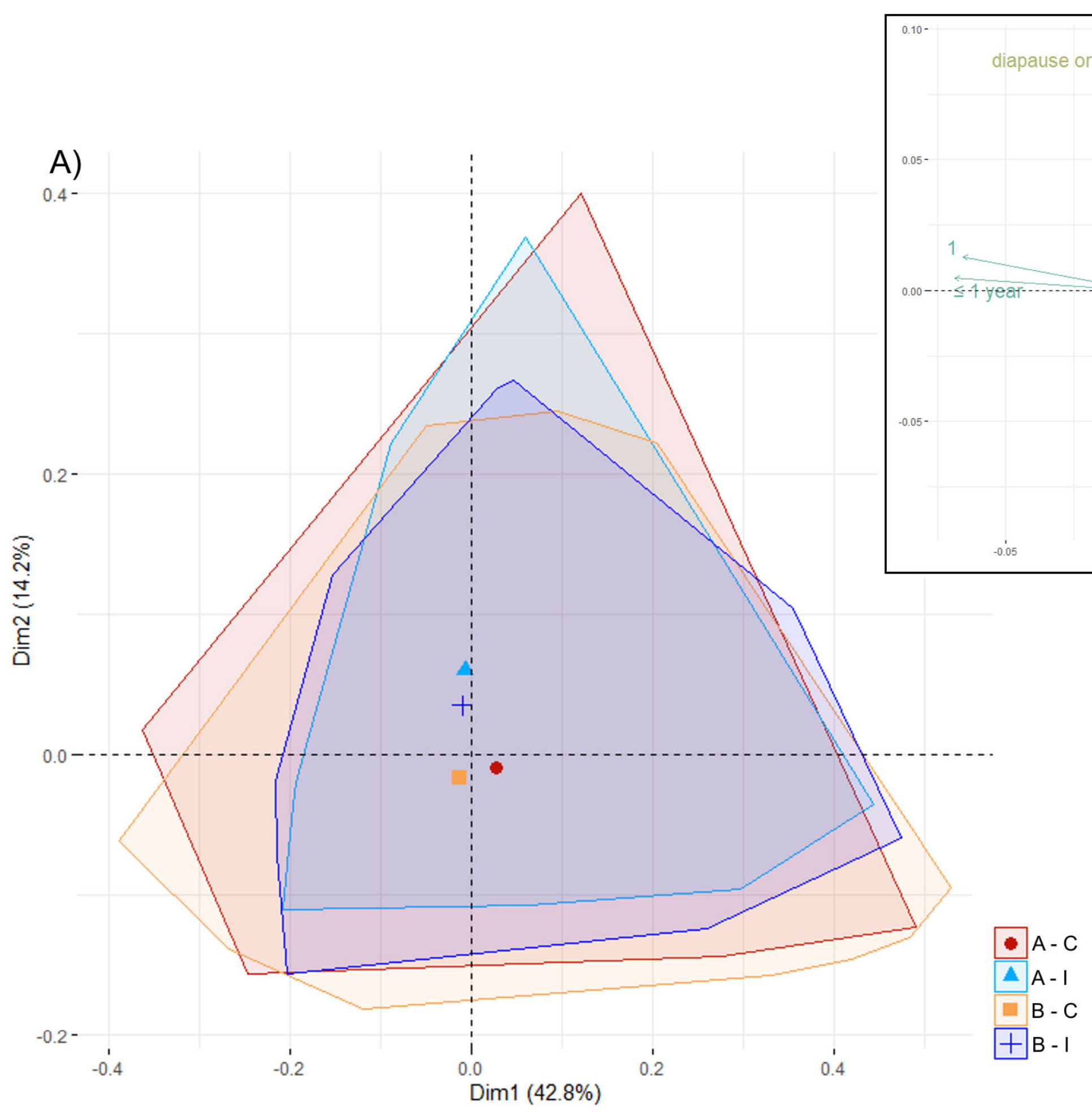

- A-C

A-I

- B - C

$+B-1$ 
S8. Results of the 1,000 simulations to assess the consistency of the outputs for function composition analysis at all levels (national, basin, season). Slope and distance between the before and after of the invaded and control samples have been assessed.

Mean and $95 \%$ coefficient intervals are shown.

Distance $=\mathrm{n}$. of time the distance between centroids (before vs after) is greater for invaded samples $(1=100 \%)$.

\begin{tabular}{lccccc}
\hline Variable & National level & Trent Basin & Thames Basin & Spring & Autumn \\
\hline distance & 0.278 & 1 & 0.339 & 0.438 & 0.362 \\
control slope & 0.0001312770 & 0.0004761103 & 0.0002167011 & 0.0001821799 & 0.0002038475 \\
ctrl_2.5 & 0.0000061544 & 0.0000210572 & 0.0000109909 & 0.000079018 \\
ctr197.5 & 0.0006084933 & 0.0068468330 & 0.0019105820 & 0.0010641470 & 0.0008432789 \\
invaded slope & 0.0050451060 & 0.0138276369 & 0.0052501630 & 0.0037383440 & 0.0081910243 \\
inv_2.5 & 0.0016019010 & 0.0041364090 & 0.0013485020 & 0.0014455900 & 0.0025293910 \\
inv_97.5 & 0.1377811340 & 0.3073714660 & 0.1210929770 & 0.0858765200 & 0.1846265000 \\
\hline
\end{tabular}


S9. Linear Mixed Model (LMMs) results for all biological indices considered in the BACI analysis at the basin (Trent and Thames) level.

BA : CI= interaction (Before-After) : (Control-Impact). ${ }^{* * *} \mathrm{p}<0.001 ;{ }^{*} \mathrm{p}<0.01 ;{ }^{*} \mathrm{p}<0.05$

\begin{tabular}{|c|c|c|c|c|c|}
\hline \multicolumn{6}{|l|}{ TRENT } \\
\hline \multicolumn{6}{|l|}{ WHPT } \\
\hline Variable & Sum Sq & DenDF & F value & $p$-value & \\
\hline $\mathrm{BA}$ & 0.0785 & 40.76 & 0.2585 & 0.6139 & \\
\hline CI & 0.4292 & 133.77 & 1.4139 & 0.2365 & \\
\hline $\mathrm{BA}: \mathrm{CI}$ & 5.5323 & 2491.64 & 18.2243 & $2.04 \mathrm{E}-05$ & $* * *$ \\
\hline \multicolumn{6}{|c|}{ WHPT- ASPT } \\
\hline Variable & Sum Sq & DenDF & F value & $p$-value & \\
\hline $\mathrm{BA}$ & 3.2109 & 40.02 & 26.4891 & $7.40 \mathrm{E}-06$ & $* * *$ \\
\hline CI & 0.617 & 132.23 & 5.0898 & 0.025709 & $*$ \\
\hline $\mathrm{BA}: \mathrm{CI}$ & 0.8702 & 2484.66 & 7.1785 & 0.007427 & $* *$ \\
\hline \multicolumn{6}{|l|}{ LIFE } \\
\hline Variable & Sum Sq & DenDF & F value & $p$-value & \\
\hline $\mathrm{BA}$ & 1.62697 & 48.04 & 8.9184 & 0.004433 & $* *$ \\
\hline CI & 2.53097 & 133.28 & 13.8739 & 0.000288 & $* * *$ \\
\hline BA:CI & 0.98441 & 2490.78 & 5.3962 & 0.020261 & $*$ \\
\hline \multicolumn{6}{|l|}{ PSI } \\
\hline Variable & Sum Sq & DenDF & F value & $p$-value & \\
\hline $\mathrm{BA}$ & 1.8233 & 42.25 & 10.7194 & 0.00212 & $* *$ \\
\hline $\mathrm{CI}$ & 3.5142 & 133.03 & 20.6607 & $1.22 \mathrm{E}-05$ & $* * *$ \\
\hline BA:CI & 0.0873 & 2487.47 & 0.5132 & 0.47383 & \\
\hline
\end{tabular}

Func. Richness

Variable Sum $\mathrm{Sq}$ DenDF F value p-value

\begin{tabular}{lrrrc} 
BA & 22.424 & 48 & 33.8088 & $4.81 \mathrm{E}-07 * * *$ \\
CI & 0.07 & 135.06 & 0.1055 & 0.7458 \\
BA:CI & 53.262 & 2496.5 & 80.3034 & $<2.2 \mathrm{E}-16 * * *$ \\
\hline
\end{tabular}

Func. Redundancy

Variable Sum Sq DenDF F value p-value

$\begin{array}{lllll}\text { BA } & 0.5501 & 39.46 & 0.7849 & 0.381\end{array}$

$\begin{array}{lllll}\text { CI } & 0.0001 & 138.05 & 0.0001 & 0.9916\end{array}$

BA:CI $\quad 12.2417 \quad 2514.07 \quad 17.4653 \quad 3.03 \mathrm{E}-05 * * *$

\begin{tabular}{|c|c|c|c|c|c|}
\hline THAME & & & & & \\
\hline WHPT & & & & & \\
\hline Variable & Sum Sq & DenDF & F value & p-value & \\
\hline BA & 0.2952 & 42.2 & 0.8284 & 0.3679 & \\
\hline CI & 0.6282 & 83.01 & 1.7629 & 0.1879 & \\
\hline BA:CI & 14.9286 & 2500.7 & 41.8925 & $1.16 \mathrm{E}-10$ & $* * *$ \\
\hline WHPT - & $\overline{\mathrm{SPT}}$ & & & & \\
\hline Variable & Sum $\mathrm{Sq}$ & DenDF & F value & $p$-value & \\
\hline BA & 2.06459 & 59.46 & 9.8703 & 0.002618 & $* *$ \\
\hline CI & 0.32542 & 81.83 & 1.5557 & 0.215849 & \\
\hline BA:CI & 1.01764 & 2510.58 & 4.8651 & 0.027496 & $*$ \\
\hline LIFE & & & & & \\
\hline Variable & Sum Sq & DenDF & F value & p-value & \\
\hline BA & 0.6664 & 56.54 & 2.0796 & 0.154799 & \\
\hline CI & 3.7544 & 82.27 & 11.7165 & 0.000968 & $* * *$ \\
\hline $\mathrm{BA}: \mathrm{CI}$ & 0.7303 & 2507.8 & 2.279 & 0.131266 & \\
\hline
\end{tabular}


PSI

Variable Sum $\mathrm{Sq}$ DenDF F value $p$-value $\begin{array}{lllll}\text { BA } & 0.8672 & 54.46 & 3.0463 & 0.086564\end{array}$

$\begin{array}{lllllll}\text { CI } & 8.4074 & 82.41 & 29.5334 & 5.47 \mathrm{E}-07 & * * *\end{array}$

$\begin{array}{llllll}\text { BA:CI } & 3.6285 & 2509.44 & 12.7463 & 0.000363 & * * *\end{array}$

Func. Richness

Variable Sum Sq DenDF F value p-value

$\begin{array}{llllll}\text { BA } & 4.3097 & 43.92 & 6.3064 & 0.015784\end{array} *$

$\begin{array}{llllll}\text { CI } & 3.5397 & 91.3 & 5.1797 & 0.025191\end{array}$ *

\begin{tabular}{llllll}
$\mathrm{BA}: \mathrm{CI}$ & 7.1517 & 2514.7 & 10.4651 & 0.001232 & $* *$ \\
\hline
\end{tabular}

Func. Redundancy

Variable Sum Sq DenDF F value p-value

$\begin{array}{lllll}\text { BA } & 1.3785 & 40.33 & 1.8505 & 0.181278\end{array}$

$\begin{array}{lllll}\text { CI } & 6.5824 & 93.65 & 8.8361 & 0.003754\end{array} * *$

$\begin{array}{llllll}\mathrm{BA}: \mathrm{CI} & 14.8446 & 2516.47 & 19.927 & 8.40 \mathrm{E}-06 & * * *\end{array}$ 


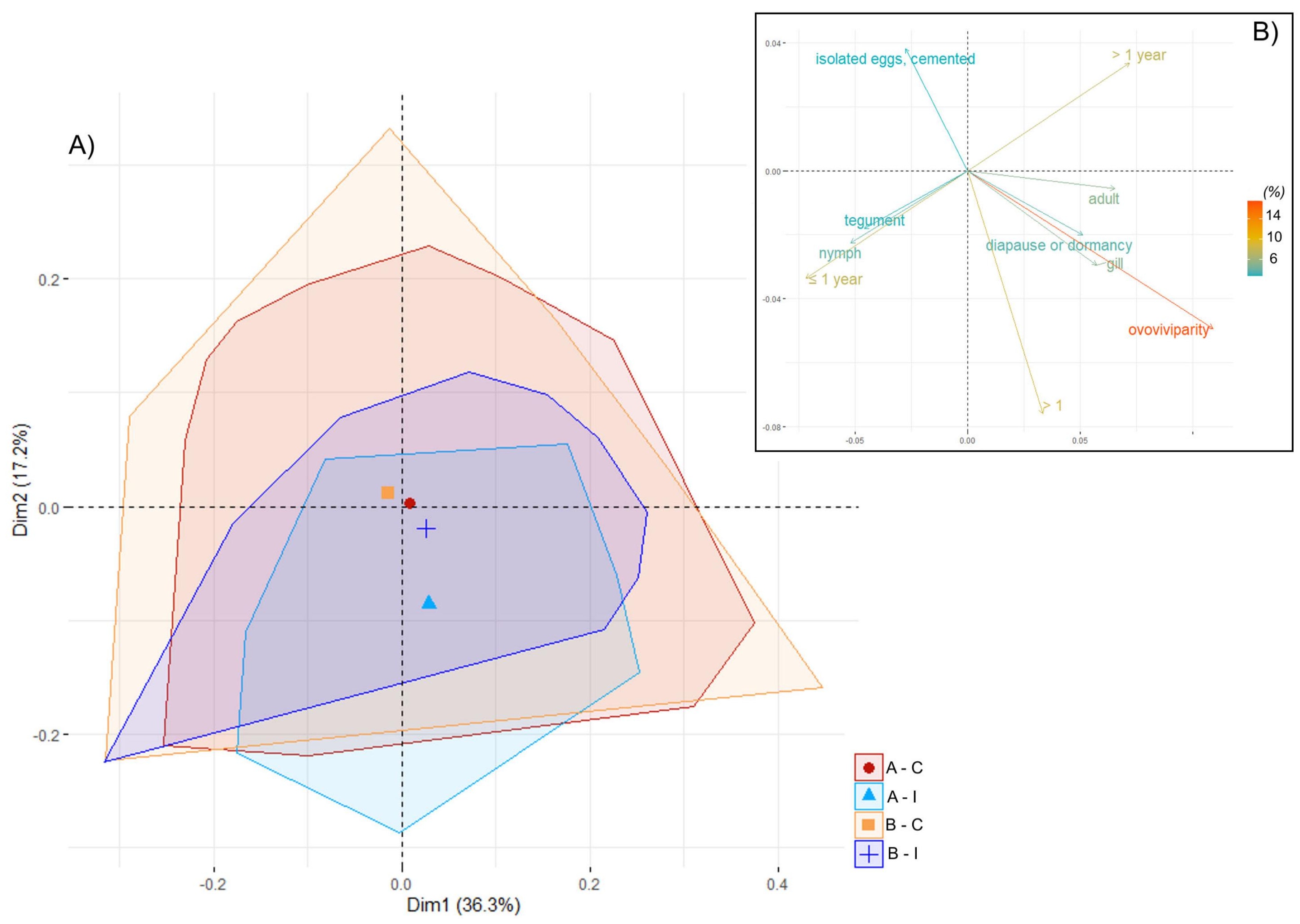




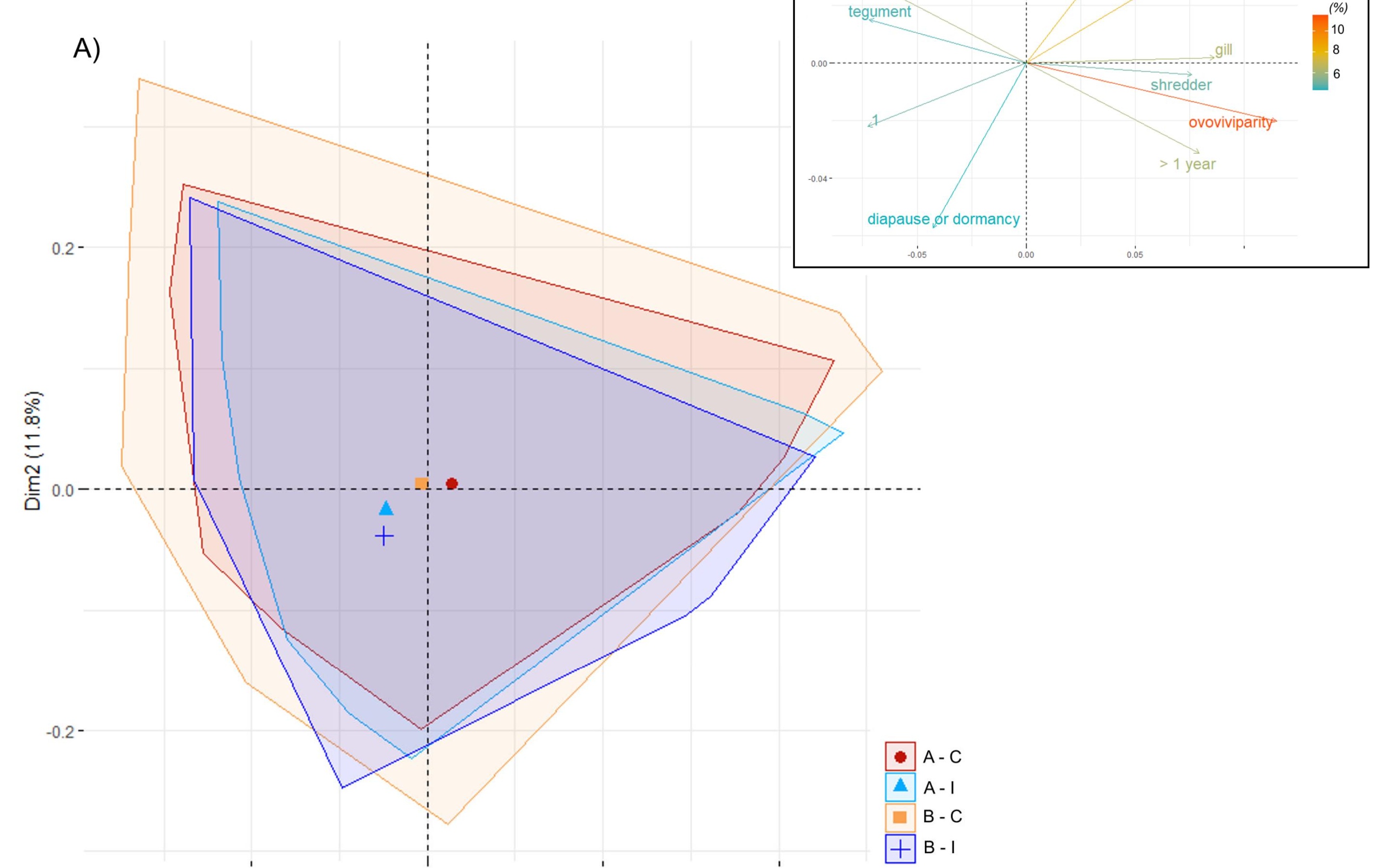

